\title{
Export and degassing of terrestrial carbon through watercourses draining a temperate podzolized catchment
}

\author{
Pierre Polsenaere $\cdot$ Nicolas Savoye $\cdot$ Henri Etcheber • \\ Mathieu Canton • Dominique Poirier • Steven Bouillon • \\ Gwenaël Abril
}

Received: 28 July 2011/Accepted: 7 August 2012/Published online: 25 August 2012

(C) Springer Basel AG 2012

\begin{abstract}
We measured spatial and temporal variations in carbon concentrations, isotopic compositions and exports during a complete hydrological cycle in nine watercourses draining a lowland forested podzolized catchment, flowing into the Arcachon lagoon (France). In addition, integrated fluxes of $\mathrm{CO}_{2}$ across the water-atmosphere interface were estimated to assess the relative importance of $\mathrm{CO}_{2}$ evasion versus lateral carbon transport at the catchment scale. Watercourse similarities and specificities linked to the local catchment characteristics are discussed and compared with other riverine systems. Low concentrations of suspended particulate matter and particulate organic carbon (POC) were generally measured in all the watercourses $(8.4 \pm 3.4$ and $1.6 \pm 0.6 \mathrm{mg} \mathrm{L}^{-1}$, respectively), reflecting limited mechanical soil erosion. The generally high POC content in the suspended matter (20\%), low Chl $a$ concentrations $\left(1.3 \pm 1.4 \mu \mathrm{g} \mathrm{L}^{-1}\right)$ and the relatively constant $\delta^{13} \mathrm{C}$-POC value (near $-28 \%$ ) throughout the year reveal this POC originates from terrestrial $\mathrm{C}_{3}$ plant and soil detritus. The presence of podzols leads to high levels of dissolved organic
\end{abstract}

P. Polsenaere $(\square) \cdot$ N. Savoye $\cdot$ H. Etcheber $\cdot$ M. Canton ·

D. Poirier · G. Abril

Laboratoire Environnements et Paléoenvironnements

Océaniques et Continentaux (EPOC), Université Bordeaux 1,

CNRS-UMR 5805, Avenue des Facultés, 33405 Talence, France

e-mail: p.polsenaere@epoc.u-bordeaux1.fr

Present Address:

P. Polsenaere

Ecosystem Studies Department, Royal Netherlands Institute

for Sea Research (NIOZ Yerseke), Korringaweg 7,

4401 NT Yerseke, The Netherlands

S. Bouillon

Department of Earth and Environmental Sciences,

Katholieke Universiteit Leuven, Leuven, Belgium carbon (DOC; $6.6 \pm 2.2 \mathrm{mg} \mathrm{L}^{-1}$ ). Similarly, high dissolved inorganic carbon (DIC) concentrations were measured in the Arcachon lagoon catchment $\left(5.9 \pm 2.2 \mathrm{mg} \mathrm{L}^{-1}\right)$. The $\delta^{13} \mathrm{C}$ DIC value around $-20 \%$ o throughout the year in many small watercourses reveals the predominance of terrestrial carbon mineralisation and silicate rock weathering in soils as the major DIC source. With $p \mathrm{CO}_{2}$ between 1,000 and $10,000 \mathrm{ppmv}$, all watercourses were a source of $\mathrm{CO}_{2}$ to the atmosphere, particularly during the low river stage. Organic carbon parameters remained relatively stable throughout the year, whereas DIC parameters showed strong seasonal contrasts closely linked to the hydrological regime and hyporheic flows. In total, the carbon export from the Arcachon watershed was estimated at $15,870 \mathrm{t} \mathrm{C}$ year $^{-1}$ or $6 \mathrm{t} \mathrm{C} \mathrm{km}^{-2}$ year $^{-1}$, mostly exported to the lagoon as DOC (35\%), DIC (24\%) and lost as $\mathrm{CO}_{2}$ degassing to the atmosphere (34\%).

Keywords Podzolized catchment - Coastal lagoon . Carbon dynamics $\cdot$ Carbon export $\cdot \mathrm{CO}_{2}$ degassing

\section{Introduction}

Rivers deliver significant amounts of terrestrially-derived carbon from the land to the sea, representing the main linkage between these two reservoirs. Approximately $0.9 \mathrm{Gt} \mathrm{C}_{\mathrm{Cear}}{ }^{-1}$ is discharged by rivers to oceans (Meybeck 1982). Of this total carbon flux value, about $40 \%$ is organic and $60 \%$ is inorganic. Meybeck (1993) computed a carbon flow carried to the ocean by temperate rivers of 19.4, 20.3 and $60.3 \%$ for DOC, POC and DIC, respectively, and proportions of 37:18:45 for DOC:POC:DIC in global rivers. However, the role of rivers in the global carbon cycle is not limited to passive transport. In fact, a 
large part of the carbon that is lost from terrestrial systems degasses as $\mathrm{CO}_{2}$ to the atmosphere from the surfaces of inland waters and does not reach the ocean (Cole et al. 2007; Tranvik et al. 2009). Recent data compilations suggest that, globally, the degassing of $\mathrm{CO}_{2}$ from inland waters could be occurring at levels that are similar to or larger than the carbon export to the ocean. Cole et al. (2007) suggest that, of the at least $1.9 \mathrm{Pg} \mathrm{C}_{\text {year }}{ }^{-1}$ that is received by inland waters from land, $40 \%$ is returned as $\mathrm{CO}_{2}$ to the atmosphere, $12 \%$ is sequestered in sediments and the remaining $48 \%$ is transported to the ocean. The revision of this "active pipe" hypothesis, advanced by Cole et al. (2007) by Tranvik et al. (2009), increased the total amount of organic carbon that was imported to inland waters from the terrestrial environment to $2.9 \mathrm{Pg} \mathrm{C}_{\mathrm{Cear}}{ }^{-1}$, of which $48 \%$ is the degassing of $\mathrm{CO}_{2}$ (from instream, soil and groundwater respiration), $21 \%$ is buried in sediments and $31 \%$ reaches the ocean.

The concentration and composition of carbon in river waters is partly a product of instream processes, but is in its majority regulated by upland, riparian and hyporheic/ groundwater processes that determine solute and gaseous inputs into aquatic systems (Jones and Mulholland 1998). In most rivers, the particulate organic carbon (POC) is mainly allochthonous and originates from soil erosion. Under particular conditions, significant changes in POC sources can occur (i.e. during storms). Additionally, in eutrophic rivers, phytoplankton developments can highly contribute to autochthonous POC (Abril et al. 2002; Neal et al. 2006). Dissolved organic carbon (DOC) in unpolluted rivers mostly originates from leachable organic carbon in soils and from terrestrial vegetation (Meybeck 1993; Sobek et al. 2007). This DOC is often considered to be mainly recalcitrant to microbial degradation and is almost entirely transported to the ocean (Mantoura and Woodward 1983). However, part of this DOC serves as a substrate for heterotrophic bacteria and fuels the aquatic trophic chain through the microbial loop in freshwaters (Pace et al. 2004). Additionally, autochthonous labile DOC can be produced within rivers by phytoplankton (Bianchi et al. 2004). The DIC in river waters has three main sources: soil $\mathrm{CO}_{2}$, bedrock and soil minerals through carbonate and silicate dissolution and atmospheric $\mathrm{CO}_{2}$ exchange at the air/water interface (Yang et al. 1996). Most rivers and lakes are net heterotrophic and emit carbon dioxide $\left(\mathrm{CO}_{2}\right)$ to the atmosphere (Jones et al. 2003; Sobek et al. 2005; Billett and Moore 2008). $\mathrm{CO}_{2}$ is typically supersaturated in streams or rivers that are connected to $\mathrm{CO}_{2}$-rich groundwater and soils. It can also be due to instream respiration and organic matter decomposition which exceeds primary production in the river itself (Jones and Mulholland 1998; Cole and Caraco 2001). Thus, inland aquatic systems are almost net annual sources of $\mathrm{CO}_{2}$ to the atmosphere (Cole et al. 1994; Hope et al. 1994; Jones et al. 2003). The $\mathrm{CO}_{2}$ that is found in freshwater is also influenced by silicate and carbonate rock weathering, producing carbonate alkalinity rather than dissolved $\mathrm{CO}_{2}$ (Yang et al. 1996; Amiotte-Suchet et al. 1999). In the presence of carbonate rocks on the watershed, one half of the total alkalinity (TA) originates from the rock, with the rest being atmospheric carbon that has been fixed on land and recycled in the soils; these rivers generally have a high $\mathrm{pH}$, high dissolved inorganic carbon (DIC) and TA, and a relatively ${ }^{13} \mathrm{C}$-enriched stable isotopic composition of DIC (Barth et al. 2003). When, in contrast, silicate rock weathering is dominant, a major part of the DIC originates from soil organic matter mineralisation and soil $\mathrm{CO}_{2}$ from root respiration; these rivers are acidic, have low TA and a large fraction of the DIC is present as excess $\mathrm{CO}_{2}$ with respect to the atmospheric equilibrium (AmiotteSuchet et al. 1999).

Thus far, several studies on inland water carbon dynamic and export to oceans have been carried out; for instance, in estuaries (Frankignoulle et al. 1998; Abril et al. 2002), lakes (Kling et al. 1992; Cole et al. 1994), large rivers (Meybeck 1993; Hope et al. 1994; Gaillardet et al. 1999) and stream waters (Hynes 1983; Neal and Hill 1994; Jones and Mulholland 1998). A few studies have dealt with watercourses in lowland catchment, with acidic organic matter-enriched soils and attempted to estimate not only carbon lateral export as particles and solutes but also $\mathrm{CO}_{2}$ degassing to the atmosphere along the entire watercourse (Hope et al. 2001; Billett et al. 2004). Here, we present a 1-year survey of carbon dynamics in acidic watercourses that drain a temperate, lowland, sandy, podzolized catchment and flow into the Arcachon lagoon (southwest of France). In this paper, we describe and explain the dynamics of all the carbon forms (except methane) i.e. particulate, dissolved, organic, inorganic and gaseous in these watercourses, and we quantify the carbon export to the lagoon taking into account the $\mathrm{CO}_{2}$ degassing to the atmosphere. Finally, we establish a regional carbon budget that can be compared to other studies and to the net ecosystem production upstream inland and downstream in the lagoon.

\section{Materials and methods}

Study site

The study area is located in the Arcachon lagoon catchment in south-western France $\left(44^{\circ} 78^{\prime} \mathrm{N}, 01^{\circ} 16^{\prime} \mathrm{W}\right.$ northerly and $44^{\circ} 64^{\prime} \mathrm{N} 01^{\circ} 12^{\prime} \mathrm{W}$ southerly). The lagoon receives freshwater from several watercourses (Fig. 1a; Table 1); the largest, in terms of watershed and discharge, is the Leyre River located at the south-eastern corner. In addition, 17 


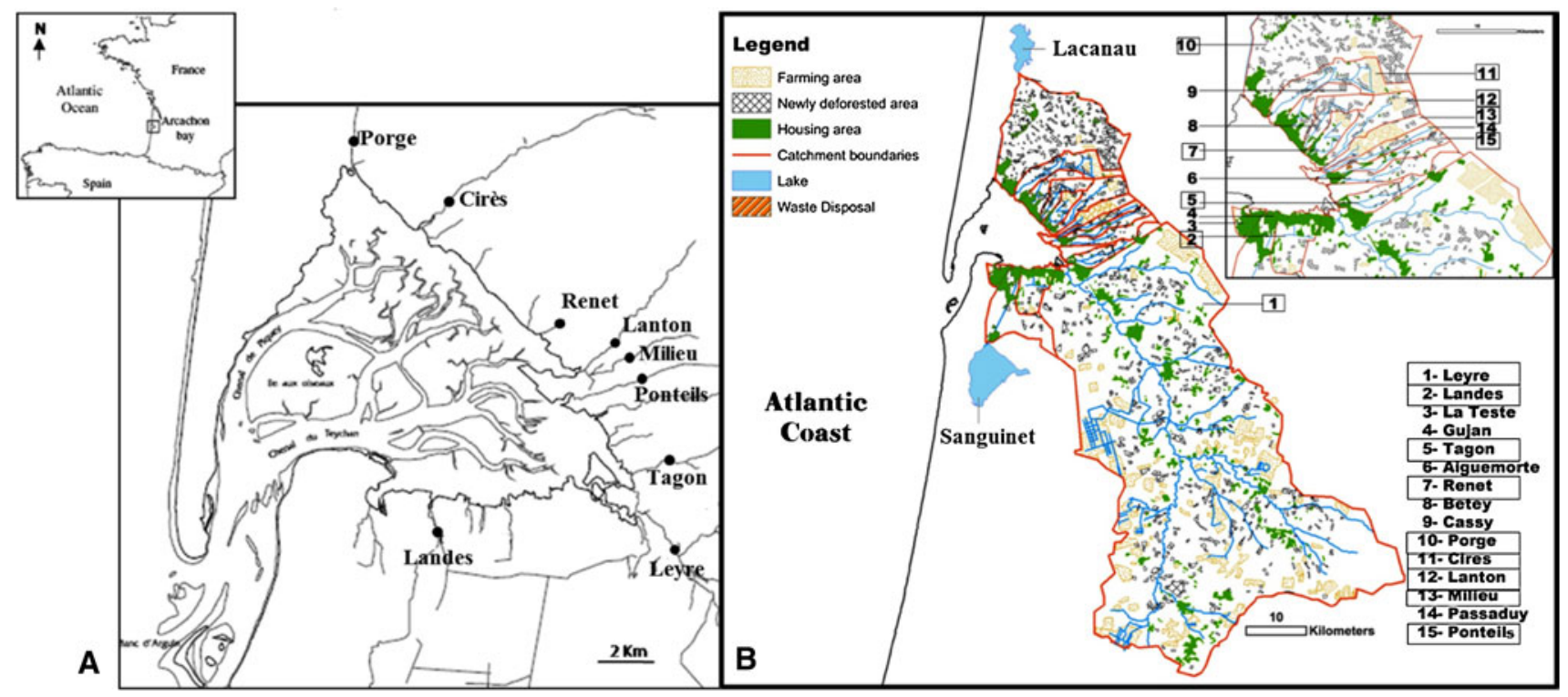

Fig. 1 Map of the Arcachon lagoon and its direct catchment basin, showing a the sampling stations for the nine watercourses, i.e., Porge, Cirès, Renet, Lanton, Milieu, Ponteils, Tagon, Leyre and Landes, and b the watercourse catchment boundaries with the soil occupation (modified from Canton et al. 2010)

Table 1 General characteristics of the nine study watercourses in the Arcachon lagoon catchment

\begin{tabular}{lcccc}
\hline & $\begin{array}{l}\text { Surface } \\
\left(\mathrm{km}^{2}\right)\end{array}$ & $\begin{array}{l}\text { Runoff } \\
\left(\mathrm{m}^{3} \mathrm{~s}^{-1}\right)\end{array}$ & $\begin{array}{l}\text { Drainage } \\
\left(\mathrm{L} \mathrm{s}^{-1} \mathrm{~km}^{-2}\right)\end{array}$ & $\begin{array}{l}\text { Population density } \\
(\text { inhab km }\end{array}$
\end{tabular}

The Leyre average runoff was calculated from daily runoffs that were measured between the sampling period by the French institute of regional environment (DIREN). The Porge, Cirès, Lanton, Ponteils and Landes runoffs were computed using the average of the measured runoffs from 1989 to 1993 (Auby et al. 1994). Other stream runoffs were estimated from watershed areas, assuming that the surface/runoff ratio equals that of the Leyre catchment

streams with very low runoff $\left(<1 \mathrm{~m}^{3} \mathrm{~s}^{-1}\right)$ are distributed all around the lagoon. Finally, two canals, Canal du Porge in the north and Canal des Landes in the south, also bring water from regulated dune lakes: the Lacanau Lake in the north and the Cazaux-Sanguinet Lake in the south (De Wit et al. 2005). The annual freshwater inputs into the lagoon average 1.25 billion $\mathrm{m}^{3}$, of which $8 \%$ is groundwater, $13 \%$ is rainfall and $79 \%$ is from watercourses (Rimmelin et al. 1998).

In total, the catchment is typical of lowlands, with a surface area of $4,138 \mathrm{~km}^{2}$ and slopes below $0.25 \%$. It is relatively homogenous topographically, climatically (isohyets between 900 and 1,000 mm) and geologically (Auby et al. 1994). The geology of the Arcachon lagoon catchment consists of a uniform quaternary sand cover, named Sable des Landes (Legigan 1979) (Fig. 1b). These soils are typical of podzols that occur on coarse, poor, siliceous parent materials (on periglacial sand deposits) under temperate humid climates (Lundström et al. 2000). These podzols are characterised by high organic acidity (pH typically between 4 and 5), low inorganic nutrient availability, and high organic carbon content that can reach $50 \mathrm{~g}$ per $\mathrm{kg}$ soil (Jolivet et al. 2007). Although mainly silicate, some Miocene-carbonated outcrops can be 
observed locally in this sandy catchment, particularly along the Leyre River (Folliot et al. 1993). In the Ponteils catchment, carbonate precipitates that are used by the landfill of the city of Audenge, closed since 2008, can also be found inside soils (Canton et al. 2010).

The Sables des Landes contains a free and continuous water table covering more than $4,000 \mathrm{~km}^{2}$, close to the Arcachon lagoon. It is formed by a homogeneous sand formation and its bottom consists of a sandy clay layer. With a variable thickness of between 10 and $130 \mathrm{~m}$, the water table is usually located very close to the surface $(\sim 3 \mathrm{~m})$. Nevertheless, on the edge of the streams, an important water table with a downward pull up exists, characterising a xerophilous lande (Jolivet et al. 2007).

The area has been massively drained and forested with pine trees (Pinus pinaster) following the imperial decree of 1,857 , and currently pine forest is the major surface cover ( $84 \%$ of the area, Fig. 1b). Intensive farming of corn and other vegetables is now prevalent in areas from 130 to $280 \mathrm{~km}^{2}$, which have replaced traditional farming areas as well as forest (Auby et al. 1994).

\section{Sampling strategy}

Different watercourse types were sampled in this study, including the Leyre River with the highest runoff $\left(18.2 \mathrm{~m}^{3} \mathrm{~s}^{-1}\right.$, representing $80 \%$ of the total freshwater inputs), the two canals and six streams with very low runoff (annual average below $0.7 \mathrm{~m}^{3} \mathrm{~s}^{-1}$ ). In total, nine watercourses from the north to the south were sampled at their outlet into the lagoon during one year, from February 2008 to February 2009 (Fig. 1a; Table 1). These nine main watercourses have been chosen for this carbon study because they cover an area spanning from the north to the south, representing about $90 \%$ of the total catchment area and nearly the entire freshwater input into the lagoon. The streams present the highest drainages-in general above $10 \mathrm{~L} \mathrm{~s}^{-1} \mathrm{~km}^{-2}$ - due to their small watershed surface, and the north and south of the Arcachon catchment show the highest population densities, above 100 inhab $\mathrm{km}^{-2}$. Consequently, these watersheds with high inhabitants to runoff ratios are subjected to more anthropogenic pressures, primarily through urban rainwater discharge, as most of the domestic load is being treated (De Wit et al. 2005).

The Renet, Ponteils and Tagon streams and the Leyre River were sampled every 2 weeks, whereas the Porge and Landes canals and the Cirès, Milieu and Lanton streams were sampled every 2 weeks. During the study, organic, inorganic, particulate, dissolved carbon forms and carbon isotopic ratios were characterised, along with other parameters in the nine watercourses of the Arcachon lagoon watershed (Figs. 2, 3; Tables 2, 3).
Field techniques

In the field, conductivity and temperature of the watercourses were measured with a portable probe, Cond340i, and $\mathrm{pH}$ was measured using a combined electrode (Metrohm) 1 min after sampling. The $\mathrm{CO}_{2}$ partial pressure $\left(p \mathrm{CO}_{2}\right)$ in watercourses was directly measured by a homemade portable equilibrator system that was used in the field following Frankignoulle et al. (2001). An Infra Red Gas Analyzer (LI-COR ${ }^{\circledR}$, LI-820) was used to measure the $p \mathrm{CO}_{2}$ in dry air that was equilibrated with freshwater. The LI-820® was calibrated at the laboratory 1 day before the field experiment using two gas standards of 0 and $2959 \pm 59$ ppmv. The equilibrator consists of a Plexiglas cylinder (height: $30 \mathrm{~cm}$, diameter: $8 \mathrm{~cm}$ ) that is filled with marbles to increase the exchange surface area. The system works as a closed system: water, through a portable peristaltic pump (Masterflex ${ }^{\circledR}, 1 \mathrm{~L} \mathrm{~min}^{-1}$ ), runs from the top to the bottom of the equilibrator, and air is pumped upwards $\left(1 \mathrm{~L} \mathrm{~min}^{-1}\right)$. The $p \mathrm{CO}_{2}$ of air equilibrates with the $p \mathrm{CO}_{2}$ of water and is then measured by the LI-COR ${ }^{\circledR}$ after being dried by a Dierite grain tube. After $7 \mathrm{~min}$. the $p \mathrm{CO}_{2}$ is constant and the entire equilibration between the air and water is achieved; then measurements are recorded with the datalogger LI-1400®.

The subsurface water was sampled and then filtered $(0.7 \mu \mathrm{m}$ of porosity) in the laboratory the same day to measure levels of SPM, POC, $\delta^{13} \mathrm{C}-\mathrm{POC}$, molar $\mathrm{C} / \mathrm{N}$ ratio and $\mathrm{Chl} a$. The filtered water was then used for a total alkalinity (TA) analysis. Dissolved organic carbon (DOC) samples were obtained after filtration in the field through pre-combusted GF/F filters (porosity of $0.7 \mu \mathrm{m}$ ) in detergent-washed and pre-combusted Pyrex vials $(25 \mathrm{~mL})$ and acidified with $50 \mu \mathrm{L}$ of $\mathrm{HCL} 37 \%$ to reach $\mathrm{pH} 2$. The DOC filtrates were stored at $4{ }^{\circ} \mathrm{C}$ before analysis at the laboratory. Water required to measure the stable isotope composition of the dissolved inorganic carbon $\left(\delta^{13} \mathrm{C}\right.$-DIC $)$ was obtained by overfilling $100 \mathrm{~mL}$ sealed glass serum vials, and kept poisoned with a saturated $\mathrm{HgCl}_{2}$ solution to avoid bacterial activity. Samples were stored in the dark before analysis.

\section{Laboratory analyses}

The water for SPM and POC measurements was filtered through pre-weighed and pre-combusted Whatman GF/F glassfibre filters $(0.7 \mu \mathrm{m}$ porosity). The filters were then dried at $60{ }^{\circ} \mathrm{C}$ and stored in the dark; subsequently, SPM was determined by the weight difference. POC was measured using the same filter; the filters were acidified in crucibles with $2 \mathrm{~N} \mathrm{HCL}$ to remove carbonates and were then dried at $60{ }^{\circ} \mathrm{C}$ (Etcheber et al. 2007). The POC content was measured by combustion using a LECO CS 125 analyser. 
The POC in $\mathrm{mg} \mathrm{L}^{-1}$ and POC in \% (of SPM) were then calculated. The uncertainty was $\pm 0.05 \%$ of SPM.

DOC concentrations were measured with a SHIMADZU TOC 5000 analyser (in TOC-IC mode), which in principle is based on thermal oxidation after a DIC removal step (Sharp 1993). The precision was close to $0.1 \mathrm{mg} \mathrm{L}^{-1}$.

Water for $\mathrm{Chl} a$ measurement was filtered through $\mathrm{GF} / \mathrm{F}$ filters, which were stored in the dark at $-80{ }^{\circ} \mathrm{C}$ until analysis. Pigments were extracted with $90 \%$ acetone, and the fluorescence was measured before and after acidification (Yentsch and Menzel 1963).

Total alkalinity (TA) was measured by titration with $\mathrm{HCl} 0.1 \mathrm{~N}$ on $100 \mathrm{~mL}$ filtered samples and was calculated by a Gran function linearisation (Gran 1952) between $\mathrm{pH}$ 4.2 and 3 . The reproducibility between the measures was better than $\pm 5 \mu \mathrm{mol} \mathrm{L}{ }^{-1}$.

Water for the measurement of $\delta^{13} \mathrm{C}-\mathrm{POC}$ and the $\mathrm{C} / \mathrm{N}$ ratio was filtered through pre-combusted GF/F filters. The filters were dried and stored in pre-cleaned glass vials; prior to the analysis, the filters were decarbonated using $\mathrm{HCl} 12 \mathrm{~N}$ and dried overnight. Measurements were performed by coupling an elemental analyser (EA; Carlo Erba NC2500) to an Isotope Ratio Mass Spectrometer (IRMS; Micromass Isoprime). The carbon isotope ratio is expressed in the delta notation $\left(\delta^{13} \mathrm{C}\right)$ relative to Pee Dee Belemnite. The $\delta^{13} \mathrm{C}$-POC levels were calibrated against the lab standards of Acetanilide $(-26.0 \%)$, Glycine $(-45.2 \%)$, Caseine $(-23.3 \%)$ and Bassin $(-17.5 \%)$, which were themselves calibrated against certified standards (IAEA-CH6, IAEA-CH7 and USGS24). The C/N ratio was calibrated against certified acetanilide. The reproducibility of the $\delta^{13} \mathrm{C}$-POC levels and the $\mathrm{C} / \mathrm{N}$ ratio was better than $\pm 0.2 \%$ and \pm 0.2 , respectively.

The $\delta^{13} \mathrm{C}$-DIC measurements were made following Gillikin and Bouillon (2007). In $100 \mathrm{~mL}$ vials that were filled to the top, a headspace was first created with Helium gas to obtain a volume of approximately $20 \%$ of the total volume of the vial. Then, $0.3 \mathrm{~mL}$ of warm $85 \%$ phosphoric acid was added to transform the carbonate forms into $\mathrm{CO}_{2}$. To ensure gas equilibration, the vials were shaken and placed upside down for $1.5 \mathrm{~h}$. The samples were measured using the above-mentioned EA-IRMS by injecting $3 \mathrm{~mL}$ of the $\mathrm{CO}_{2}$ gas that was contained in each vial headspace through an injection port that was mounted before the water trap of the EA. $\delta^{13} \mathrm{C}$-DIC was calibrated against a homemade standard $\left(45 \mathrm{mg}\right.$ of $\mathrm{Na}_{2} \mathrm{CO}_{3}$ were dissolved in a vial, flushed with $\mathrm{He}$ gas flow, with $3 \mathrm{~mL}$ of $\mathrm{H}_{3} \mathrm{PO}_{4}$ ) that had been calibrated against a certified standard (NBS19, -1.96\%) using a dual-inlet IRMS (Micromass Isoprime). The isotopic value of the standard $\mathrm{Na}_{2} \mathrm{CO}_{3}$ found was $-4.5 \pm 0.2 \%$. Finally, the equation of Miyajima et al. (1995) was applied to correct for the partitioning of the $\mathrm{CO}_{2}$ between the headspace and the water phase and to calculate the $\delta^{13} \mathrm{C}$ of the total DIC. The repeatability was approximately $\pm 0.1 \%$ between samples.

DIC concentration was calculated from the $p \mathrm{CO}_{2}$ and TA measurements (in addition to the water temperature) by resolving inorganic carbon system equations using dissociation constants from Mehrbach et al. (1973). The excess $\mathrm{CO}_{2}$, defined as the quantity of DIC that was theoretically transferred as $\mathrm{CO}_{2}$ to the atmosphere after water-air equilibration, was calculated as the difference between the in situ DIC and a theoretical DIC at the atmospheric equilibrium (i.e. $\mathrm{DIC}_{\text {equilibrium, }}$ computed for a $p \mathrm{CO}_{2}$ of 380 ppmv and the in situ TA as explained above) following Abril et al. (2000).

Hydrologic data sources, flux calculations and statistical tools

According to available hydrologic data for this study, daily runoffs measured by the French institute of regional environment (DIREN) were used to calculate the Leyre averaged runoff over the sampling period. The Porge, Cirès, Lanton, Ponteils and Landes runoffs were computed using the average of the measured runoffs from 1989 to 1993 (Auby et al. 1994). Other stream runoffs were estimated and normalized using the surface/runoff relationship between the Leyre and the other watersheds. The carbon export budget (carbon exports and carbon export rates) of the Arcachon lagoon watershed was computed using the monthly averages for carbon concentrations and watercourse runoffs over the corresponding sampling points. It was calculated for each sampled watercourse in $\mathrm{t} C$ year $^{-1}$ (carbon export) and then normalized by each corresponding watershed surface in $\mathrm{t} \mathrm{C} \mathrm{km}^{-2}$ year $^{-1}$ (carbon export rate). The total carbon export rate was then computed by adding the nine watercourse carbon export values (i.e. the total carbon export from the Arcachon lagoon watershed) divided by the total cachment surface (see Tables 1, 4, 5).

The carbon export budget from these watercourses to the lagoon included the export of each carbon forms, i.e. TOC (POC and DOC), DIC (Excess $\mathrm{CO}_{2}, \mathrm{DIC}_{\text {equilibrium }}$ and $\mathrm{CO}_{2}$ degassing). This $\mathrm{CO}_{2}$ degassing from watercourses to the atmosphere was calculated by the "StreamCO $\mathrm{C}_{2}$-DEGAS" model formulated by Polsenaere and Abril (2012) that uses water-air isotopic equilibration and equation mass balance. The inversed model uses in situ data of $p \mathrm{CO}_{2}$, total alkalinity (TA) and $\delta^{13} \mathrm{C}$-DIC and applies to small acidic and unproductive watercourses. It first makes several asumptions concerning the isotopic composition of the DIC initially released to surface waters $\left(\mathrm{CO}_{2}\right.$ from respired soil organic carbon and $\mathrm{HCO}_{3}{ }^{-}$from weathering) and on kinetic fractionation at the water-air interface $\left({ }^{12} \mathrm{CO}_{2}\right.$ degases to the atmosphere more rapidly than $\left.{ }^{13} \mathrm{CO}_{2}\right)$. It then computes a theoretical DIC concentration that has 
evaded to the atmosphere upstream of the sampling point in order to reach the observed $p \mathrm{CO}_{2}$ and $\delta^{13} \mathrm{C}$-DIC values due to gas isotopic equilibration (more details can be found in Polsenaere and Abril 2012).

The GraphPad Prism 5 and Xlstat softwares were used for statistical analysis. The Shapiro-Wilk test was used to test the normality of the data, followed by the KruskalWallis test (in the case of nonparametric data) for analysis of variance (ANOVA) and the Dunn's multiple comparison test (post-test). ANOVA was done to distinguish significant differences in carbon and associated parameters between watercourses and also between the four seasons (winter, periods from day 45 to 73 and from day 374 to 416; spring, period from day 85 to 168 ; summer, period from day 182 to 252 and autumn, period from day 267 to 351) for all watercourses.

\section{Results}

General overview of carbon concentrations and characteristics of the Arcachon lagoon catchment watercourses

General trends in terms of carbon concentations and associated parameters have been measured throughout the study year in the nine watercourses (Tables 2,3). Water temperatures were generally close to each other with a mean of $12.9 \pm 0.5^{\circ} \mathrm{C}$ and showed a typical annual trend with values ranging from $3.5^{\circ} \mathrm{C}$ during the winter months (day 374 , in the Porge canal) to $19.6{ }^{\circ} \mathrm{C}$ during the summer period (day 197, in Landes canal). Water conductivity showed little variation in all of the watercourses (near $205 \pm 31 \mu \mathrm{S} \mathrm{cm}^{-1}$ ), with the exception of the Porge canal, where conductivity reached $4,420 \mu \mathrm{S} \mathrm{cm}^{-1}$ (salinity of 1.9 ) during sampling day 295 in autumn linked to the tidal rhythm; in fact, the canal links the Lacanau lake to the lagoon in the North and is sometimes affected by tidal intrusion (Fig. 1). The SPM concentrations were low over the year in all watersheds, generally below $20 \mathrm{mg} \mathrm{L}^{-1}$. The average was $8.4 \pm 3.4 \mathrm{mg} \mathrm{L}^{-1}$; the lowest values were found in the Landes canal $\left(2.7 \pm 1.1 \mathrm{mg} \mathrm{L}^{-1}\right.$ on average) and the highest values were found in the other watercourses (near $10 \mathrm{mg} \mathrm{L}^{-1}$ on average). Similarly, the concentrations of POC $\left(1.6 \pm 0.6 \mathrm{mg} \mathrm{L}^{-1}\right.$ on average) were low in these poorly turbid waters of the lowland regions, from $0.7 \pm 0.3 \mathrm{mg} \mathrm{L}^{-1}$ in the Landes canal to only $2.49 \pm$ $2.2 \mathrm{mg} \mathrm{L}^{-1}$ in the Tagon stream (Table 2). Nevertheless, the POC content of the SPM was high with a mean of $20.8 \pm 2.7 \%$, varying from about $16 \%$ (in Leyre River) to $24 \%$ (in Porge canal). DOC concentrations were generally high with an annual average of $6.6 \pm 2.2 \mathrm{mg} \mathrm{L}^{-1}$ and the highest values of up to $8.0 \mathrm{mg} \mathrm{L}^{-1}$ occuring in Porge canal and Tagon and Ponteils streams, and the lowest values between 4.2 and $5.8 \mathrm{mg} \mathrm{L}^{-1}$ in the other watercourses. The DOC/POC ratio ranged between 2 and 8 (Table 2). $\delta^{13} \mathrm{C}$ POC was somewhat constant throughout the year with an average of $-28.6 \pm 0.4 \%$ and values ranging from $-9.2 \%$ to $-28.1 \%$ in the Landes and Porge canals, respectively. Yearly averages of molar $\mathrm{C} / \mathrm{N}$ ratios were above 12 and varied between $12 \pm 0.9$ in the Landes canal and $19.9 \pm 2.2$ in the Lanton stream (Table 2). Finally, Chl $a$ concentrations were low in the nine watercourses, with an average of $1.3 \pm 1.4 \mu \mathrm{g} \mathrm{L}^{-1}$. As a consequence, the mean $\mathrm{POC} / \mathrm{Chl} a$ ratios were always high $(2,590 \pm 1,396$ on average) from 580 to 4,200 in the Landes canal and the Milieu stream, respectively.

DIC concentrations averaged $488.0 \pm 186.1 \mu \mathrm{mol} \mathrm{L}^{-1}$ in all watercourses and ranged from 229.5 to $859.3 \mu \mathrm{mol} \mathrm{L}^{-1}$ in the Milieu and Ponteils streams, respectively (Table 3). Due to the acidic characteristic of this sandy catchment $(\mathrm{pH}$ of $6.55 \pm 0.25$ on average and values between 6.09 and 7.03, Polsenaere, unpublished data), the DIC was dominated $(>99 \%)$ by $\mathrm{HCO}_{3}{ }^{-}$and $\mathrm{CO}_{2} *$. TA was almost entirely composed of bicarbonates and was generaly low over the year in the watercourses, with an annual average of $300 \pm 135 \mu \mathrm{mol} \mathrm{L} \mathrm{L}^{-1}$ and values ranged from 104.3 to $550.4 \mu \mathrm{mol} \mathrm{L}{ }^{-1}$ on average in the Milieu and Ponteils streams respectively. In all cases, waters were largely supersaturated in $\mathrm{CO}_{2}$, with an average $p \mathrm{CO}_{2}$ of 3,922 $\pm 1,645$ ppmv and yearly averages ranging from 2,554 ppmv in the Milieu stream to 6,546 ppmv in the Ponteils streams (Table 3). As a consequence, the excess $\mathrm{CO}_{2}$ was also high in all watercourses with a mean of $170.2 \pm 78.2 \mu \mathrm{mol} \mathrm{L}^{-1}$. Finally, low values of $\delta^{13} \mathrm{C}$ DIC were generally observed during this annual cycle $(-16.7 \pm 3.5 \%$ on average) and values ranged from -20.3 to $-10.6 \%$ in the Renet and Ponteils streams, respectively (Table 3 ).

\section{Seasonnality of carbon concentrations} and characteristics of the Arcachon lagoon catchment watercourses

Throughout the annual sampling period, consistent seasonal patterns in carbon concentrations and associated parameters were observed (Figs. 2, 3) and linked to the hydrological regime in the watershed. The latter consisted of short flood periods in spring (close to $30 \mathrm{~m}^{3} \mathrm{~s}^{-1}$ ) related to high precipitation, then a low water flow throughout the summer period and finally, in the late autumn and winter, river runoff maxima reaching up to $100 \mathrm{~m}^{3} \mathrm{~s}^{-1}$ (Figs. 2, 3). Organic carbon and associated parameters showed stable seasonal patterns for each watercourse with generally no clear seasonal pattern (Fig. 2). No significant differences (ANOVA, $p>0.05$ ) were measured between each of 


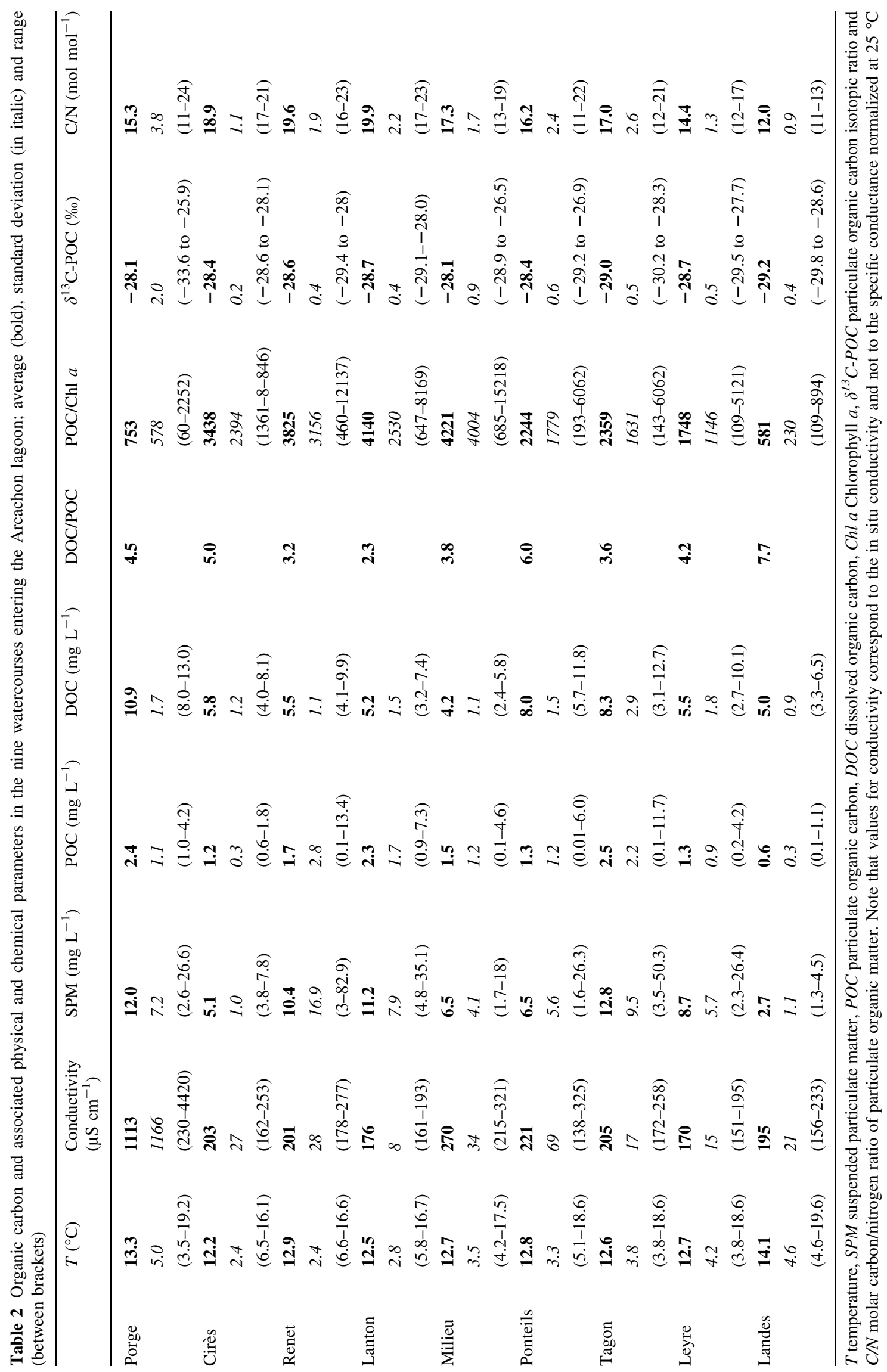


Table 3 Observed inorganic carbon parameters in the nine watercourses entering the Arcachon lagoon; average (bold), standard deviation (in italic) and range (between brackets)

\begin{tabular}{|c|c|c|c|c|c|}
\hline & $p \mathrm{CO}_{2}$ (ppmv) & $\mathrm{TA}\left(\mu \mathrm{mol} \mathrm{L}{ }^{-1}\right)$ & Excess $\mathrm{CO}_{2}\left(\mu \mathrm{mol} \mathrm{L}{ }^{-1}\right)$ & $\mathrm{DIC}\left(\mu \mathrm{mol} \mathrm{L}{ }^{-1}\right)$ & $\delta^{13} \mathrm{C}-\mathrm{DIC}(\%)$ \\
\hline \multirow[t]{3}{*}{ Porge } & 4,364 & 374.4 & 181.6 & 573.9 & -13.3 \\
\hline & 2,775 & 69.5 & 113.5 & 148.3 & 3.8 \\
\hline & $(1,192-8,380)$ & $(286-569)$ & $(48-357)$ & $(366-924)$ & $(-17.6$ to -7.5$)$ \\
\hline \multirow[t]{3}{*}{ Cirès } & 4,212 & 201.1 & 191.2 & 411.3 & -19.5 \\
\hline & 544.7 & 31.8 & 26.5 & 40.0 & 0.5 \\
\hline & $(3,020-5,280)$ & $(151-268)$ & $(133-231)$ & $(347-467)$ & $(-20.3$ to -18.3$)$ \\
\hline \multirow[t]{3}{*}{ Renet } & 5,479 & 247.5 & 247.3 & 513.2 & -20.3 \\
\hline & 1,279 & 52.4 & 54.4 & 80.8 & 0.4 \\
\hline & $(1,437-7,653)$ & $(154-370)$ & $(56-320)$ & $(317-674)$ & $(-21.2$ to -19.6$)$ \\
\hline \multirow[t]{3}{*}{ Lanton } & 3,167 & 175 & 136.9 & 330.8 & -18.6 \\
\hline & 1,057 & 85.6 & 45.8 & 95.7 & 1.4 \\
\hline & $(1,889-6,220)$ & $(83-444)$ & $(73-260)$ & $(236-612)$ & $(-21.4$ to -16.4$)$ \\
\hline \multirow[t]{3}{*}{ Milieu } & 2,554 & 104.3 & 106.4 & 229.5 & -19.7 \\
\hline & 949.8 & 22.2 & 42.5 & 55.1 & 1.7 \\
\hline & $(1,529-5,460)$ & $(78-153)$ & $(57-229)$ & $(170-390)$ & $(-24.6$ to -17.9$)$ \\
\hline \multirow[t]{3}{*}{ Ponteils } & 6,546 & 550.4 & 292.4 & 859.3 & -10.6 \\
\hline & 2,742 & 351.4 & 121.3 & 454.9 & 2.1 \\
\hline & $(2,116-10,012)$ & $(101-1,082)$ & $(98-470)$ & $(240-1,550)$ & $(-15.0$ to -7.6$)$ \\
\hline \multirow[t]{3}{*}{ Tagon } & 5,125 & 394.6 & 228.1 & 640.7 & -19.0 \\
\hline & 1,425 & 167.6 & 54.0 & 200.7 & 1.3 \\
\hline & $(2,188-7,809)$ & (128-648) & $(108-354)$ & (349-949) & $(-21.4$ to -16.9$)$ \\
\hline \multirow[t]{3}{*}{ Leyre } & 1,604 & 325 & 59.96 & 403.6 & -15.6 \\
\hline & 338.7 & 113.9 & 18.0 & 104.0 & 2.6 \\
\hline & $(1,046-2,453)$ & $(120-520)$ & $(38-114)$ & $(255-612)$ & $(-21.6$ to -12.5$)$ \\
\hline \multirow[t]{3}{*}{ Landes } & 2,250 & 324.1 & 87.58 & 429.4 & -13.8 \\
\hline & 590.6 & 60.8 & 23.0 & 55.2 & 2.4 \\
\hline & $(1,485-3,382)$ & $(279-495)$ & $(48-125)$ & $(359-583)$ & $(-16.8$ to -8.0$)$ \\
\hline
\end{tabular}

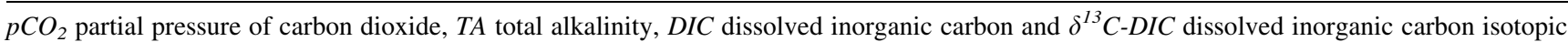
ratio

the four seasons in SPM (concentrations) and POC (concentration and \%) values even if some higher SPM values were noticed during flood events (for instance in the Leyre River, day 336 with $16.4 \mathrm{mg} \mathrm{L}{ }^{-1}$; Fig. 2c). Similarly $\delta^{13} \mathrm{C}$ POC and molar $\mathrm{C} / \mathrm{N}$ ratio values showed no clear seasonal trends. However, in Porge canal during the sample day 197 in summer, a very low value of $\delta^{13} \mathrm{C}-\mathrm{POC}(-33.6 \%)$ was measured compared to the constant observed values between -26 and $-30 \%$ throughout the year (Fig. $2 \mathrm{~g}$ ). On the same day, a higher Chl $a$ concentration was also observed in the same canal (up to $17 \mu \mathrm{L}^{-1}$ ) compared to low values generally noticed in the nine watercourses (Fig. 2m). As a consequence, POC/Chl $a$ ratios exhibited large differences between seasons, reflecting the annual pattern in Chl $a$ concentration (plot not shown). The only clear seasonal pattern for organic carbon parameters was observed in DOC concentrations, with significant differences (ANOVA, $p=0.0074$ ) between the summer and the winter/spring, where the highest values were measured (Fig. 2p-r).

In contrast to organic carbon parameters, the observed inorganic carbon parameters in the nine watercourses showed strong seasonal patterns throughout the year (Fig. 3; Table 3). Overall, significant differences in DIC parameters were noticed between the winter and summer period (ANOVA, $p<0.05$ ). In fact, $p \mathrm{CO}_{2}$ was minimum during the winter months around 1,000-2,000 ppmv and

Fig. 2 Seasonal variations in organic matter and its associated parameters in the nine study watercourses. a, b, and c Suspended particulate matter (SPM), d, e, and $\mathbf{f}$ particulate organic carbon (POC, $\%$ of SPM $), \mathbf{g}, \mathbf{h}$, and $\mathbf{i}$ stable isotope of POC $\left(\delta^{13} \mathrm{C}-\mathrm{POC}\right), \mathbf{j}, \mathbf{k}$, and I $\mathrm{C} / \mathrm{N}$ ratio of particulate organic matter, $\mathbf{m}, \mathbf{n}$, and $\mathbf{o}$ Chlorophyll $a(\mathrm{Chl} a)$ and $\mathbf{p}, \mathbf{q}$, and $\mathbf{r}$ dissolved organic carbon (DOC). Panels show the daily discharge of the Leyre River. Day 0 is January 1, 2008 and win., spr., sum. and aut. indicate the winter, spring, summer and autumn seasons, respectively 

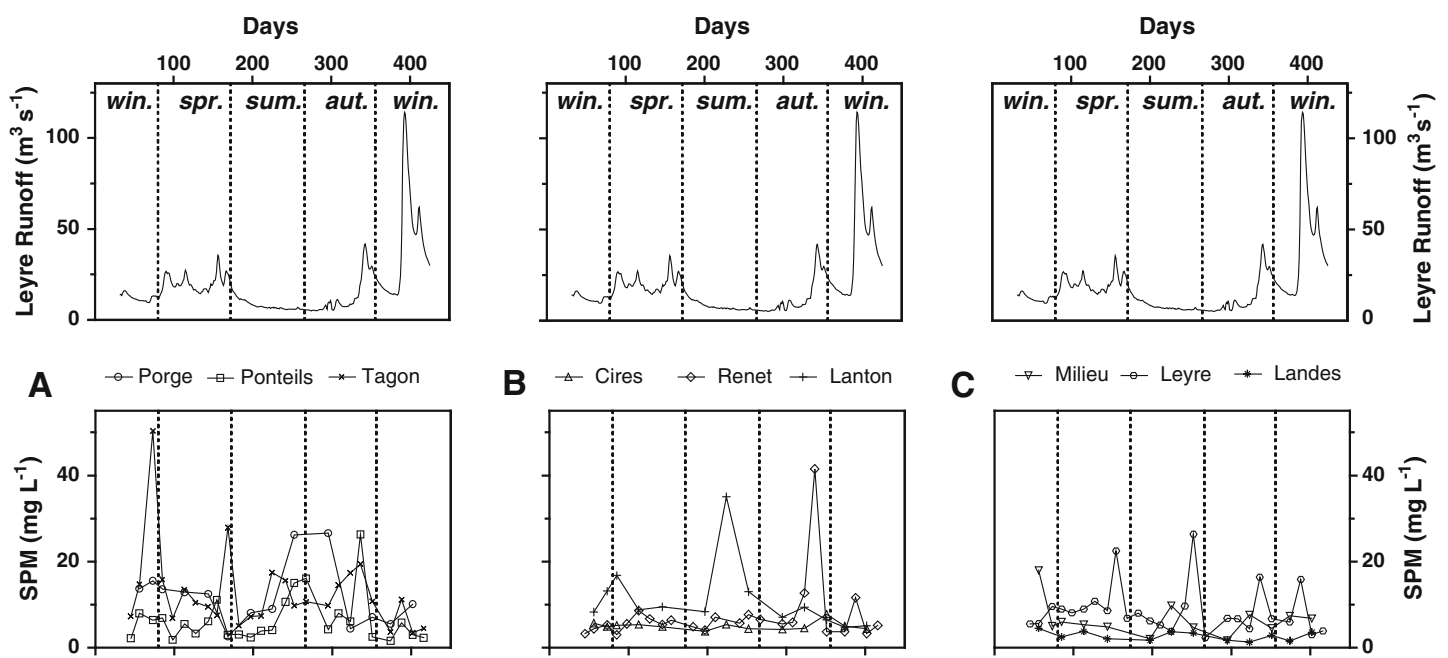

B $\triangle$ Cires $\rightarrow$ Renet + Lanton
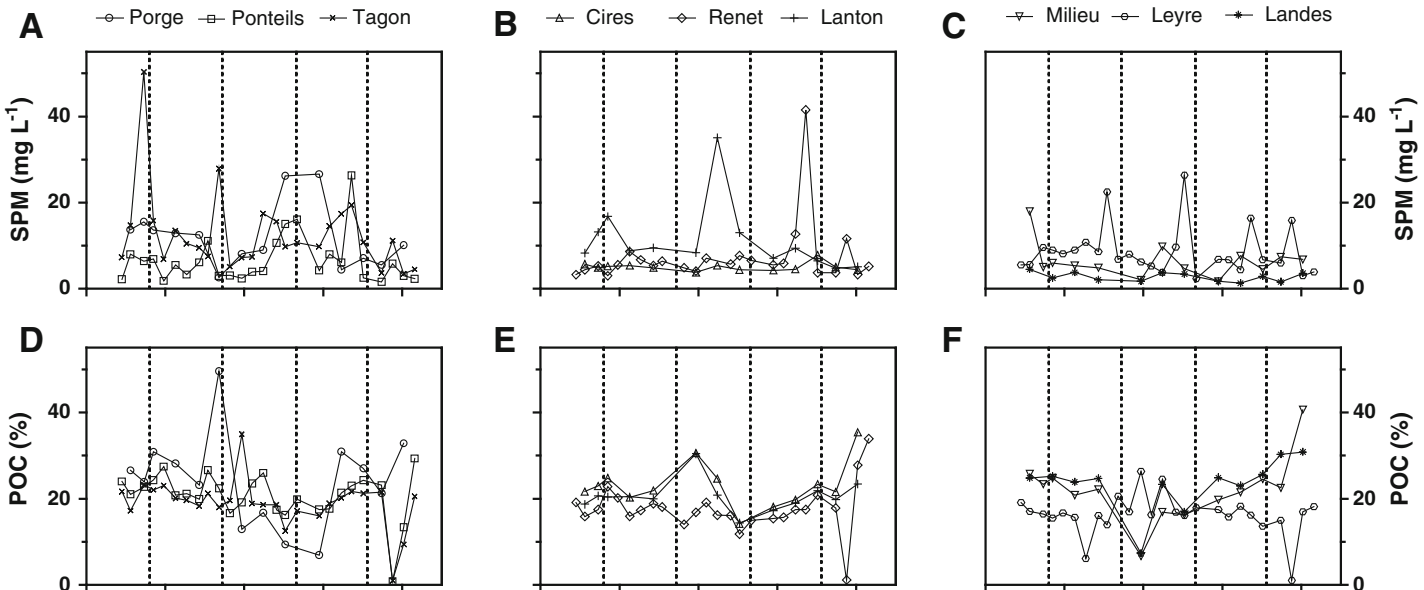

E

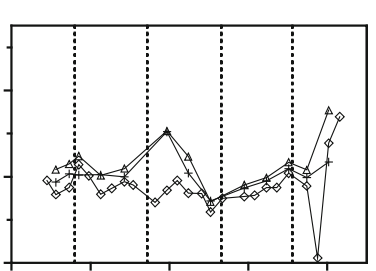

$\mathbf{F}$

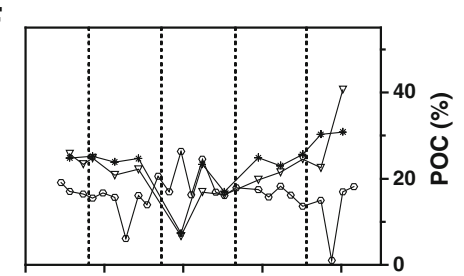

G

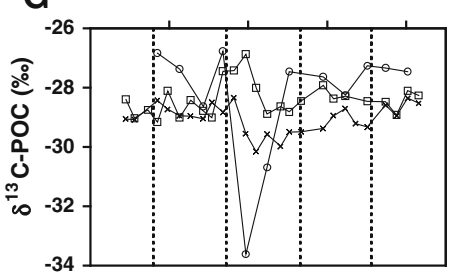

H
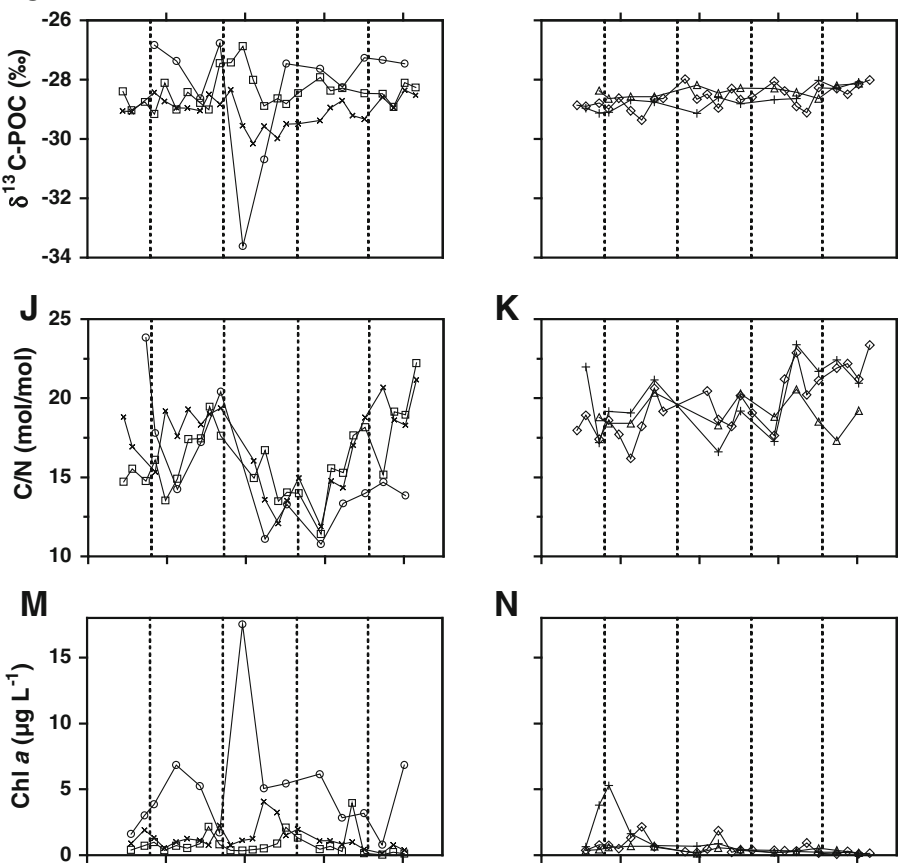

N

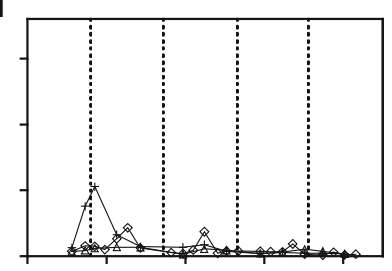

I

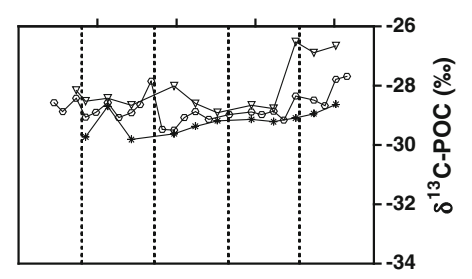

L

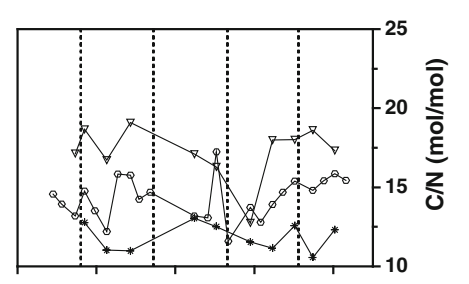

O
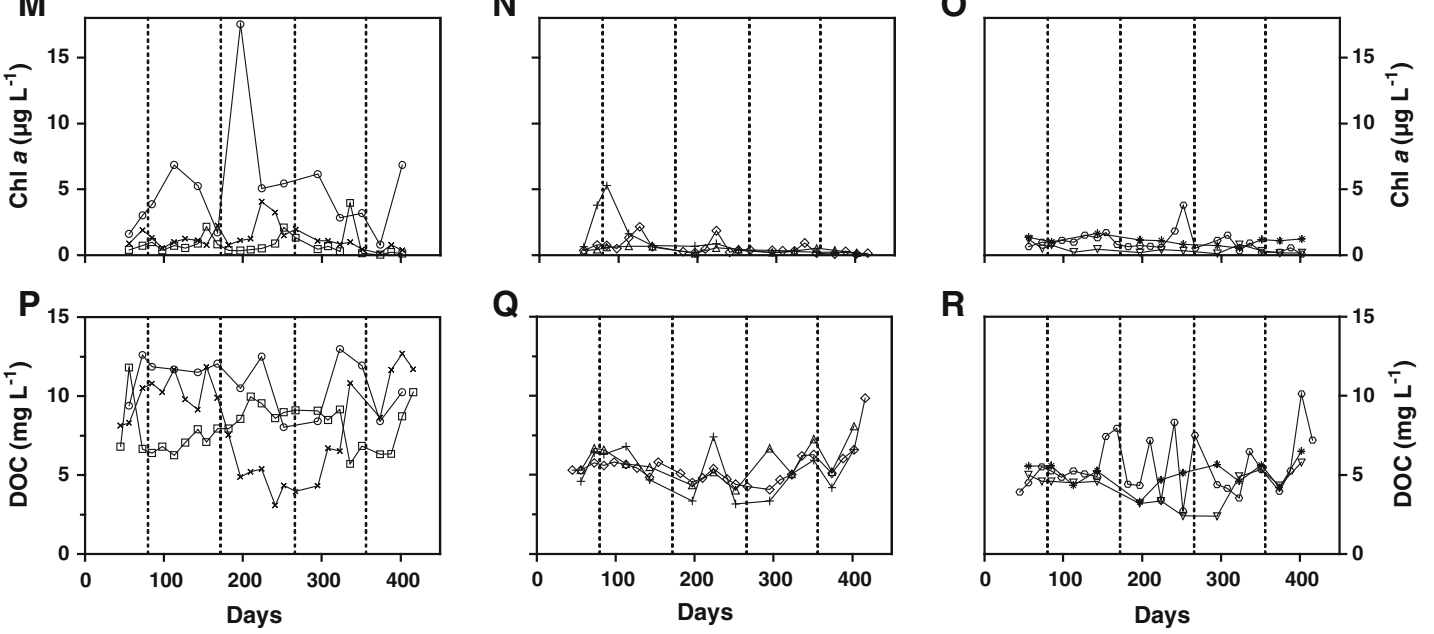

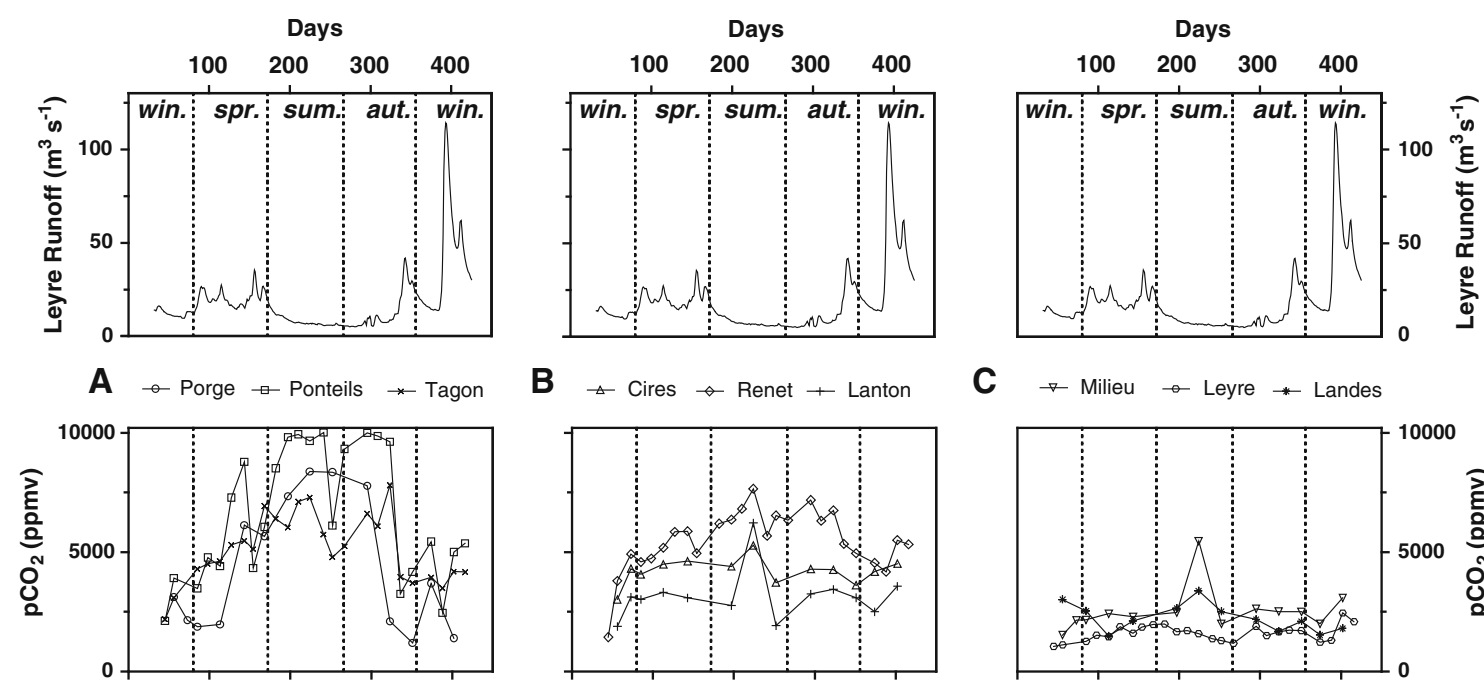

B $\triangle$ Cires $\rightarrow$ Renet + Lanton
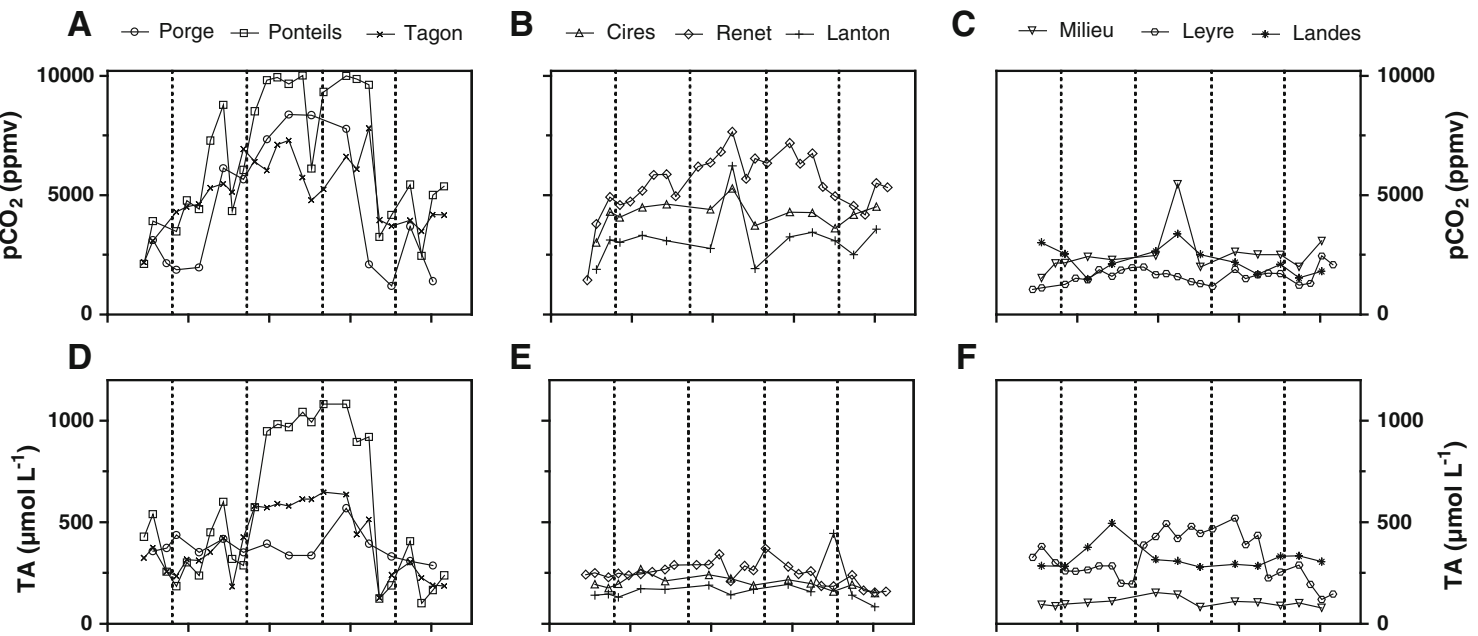

E

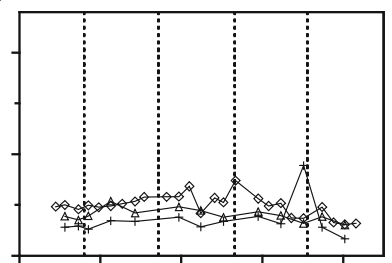

$\mathbf{F}$
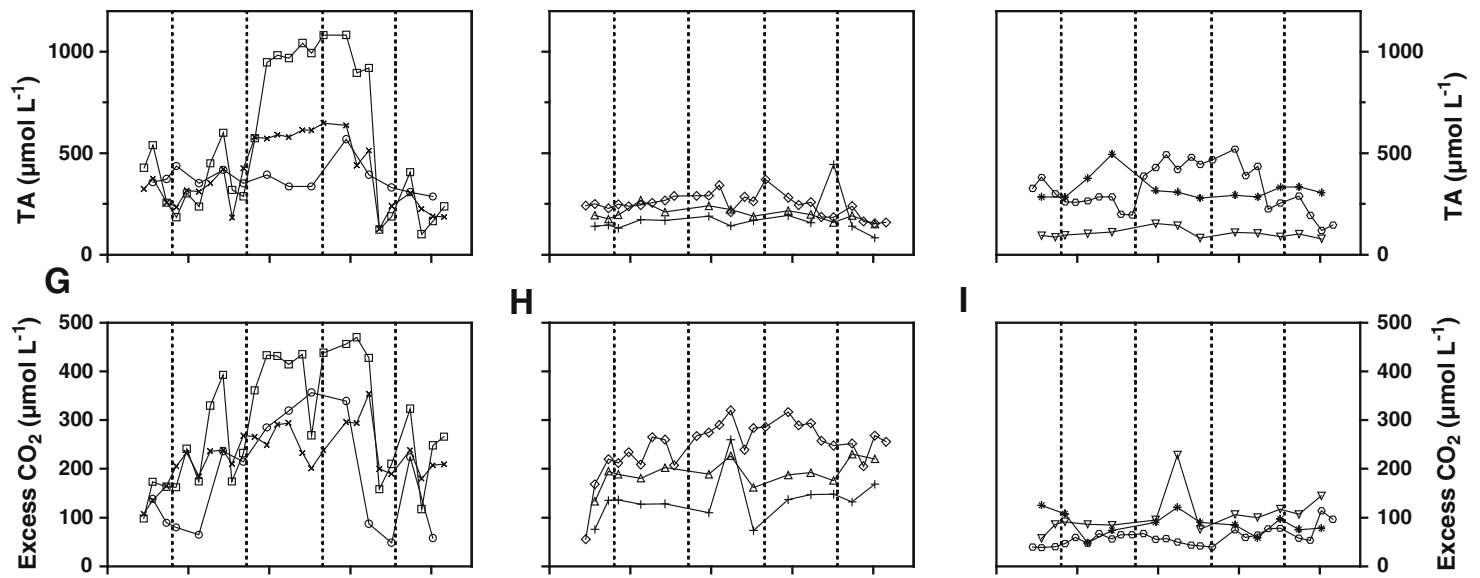

H
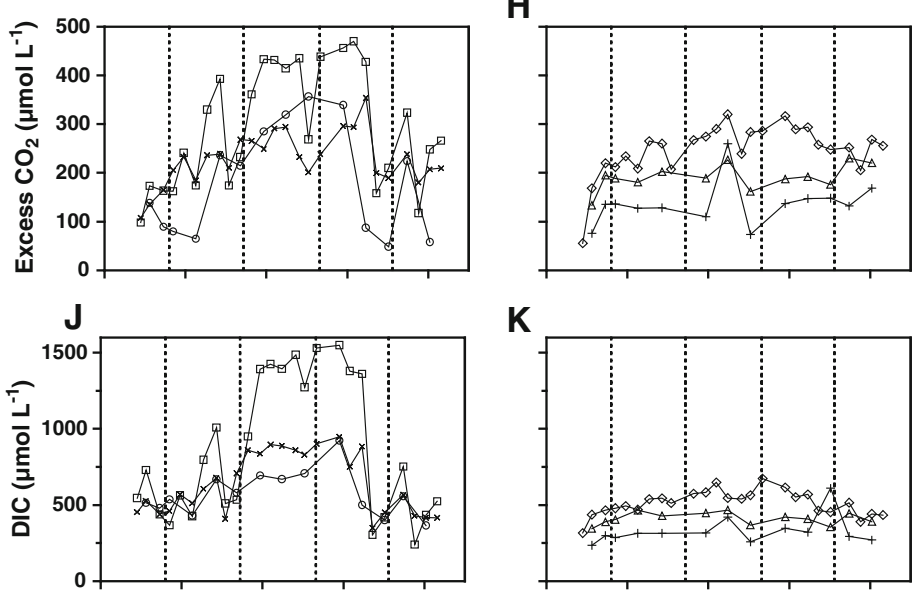

I

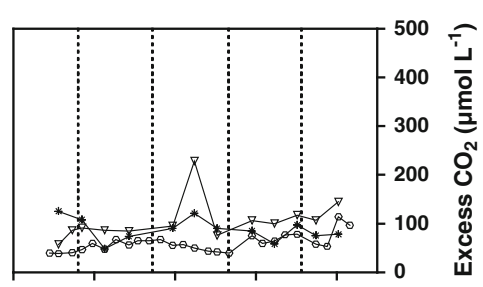

L
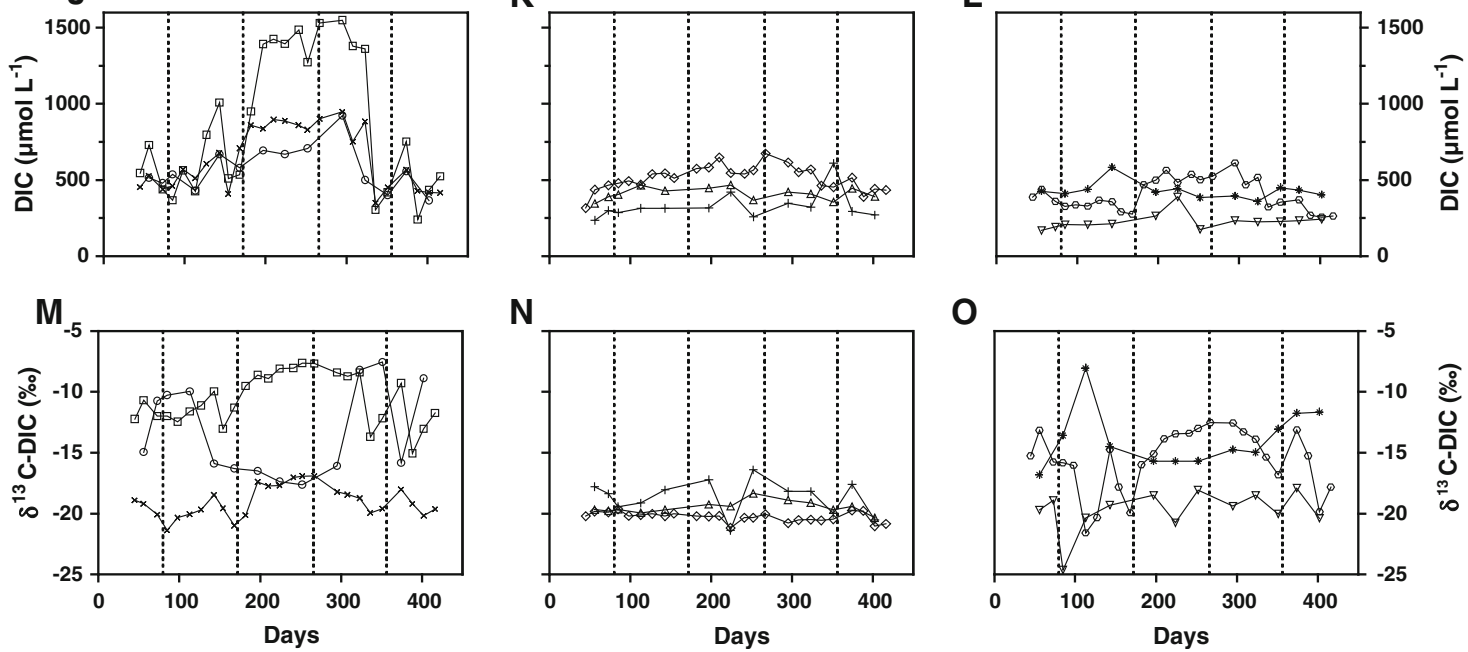

Fig. 3 Seasonal variations in the inorganic carbon and its associated parameters in the nine study watercourses. $\mathbf{a}, \mathbf{b}$, and $\mathbf{c}$ partial pressure of carbon dioxide $\left(p \mathrm{CO}_{2}\right), \mathbf{d}, \mathbf{e}$, and $\mathbf{f}$ : total alkalinity (TA), $\mathbf{g}, \mathbf{h}$, and $\mathbf{i}$ excess of carbon dioxide (excess $\left.\mathrm{CO}_{2}\right), \mathbf{j}, \mathbf{k}$, and $\mathbf{l}$ dissolved

inorganic carbon (DIC) and $\mathbf{m}, \mathbf{n}$ and $\mathbf{o}$ stable isotope of DIC $\left(\delta^{13} \mathrm{C}\right.$ DIC). Panels show the daily discharge of the Leyre River. Day 0 is January 1, 2008 and win., spr., sum. and aut. indicate the winter, spring, summer and autumn seasons, respectively 
Fig. 4 a Suspended particulate matter (SPM), b partial pressure of carbon dioxide $\left(p \mathrm{CO}_{2}\right)$, c particulate organic carbon (POC, \% of SPM), d total alkalinity (TA), e particulate organic carbon (POC), $\mathbf{f}$ excess of carbon dioxide (excess $\mathrm{CO}_{2}$ ), $\mathbf{g}$ dissolved organic carbon (DOC), $\mathbf{h}$ dissolved inorganic carbon (DIC), i stable isotope of POC $\left(\delta^{13} \mathrm{C}-\mathrm{POC}\right), \mathbf{j}$ stable isotope of DIC ( $\delta^{13} \mathrm{C}$-DIC), k chlorophyll $a(\mathrm{Chl} a)$ and 1 molar carbon/nitrogen ratio of organic matter $(\mathrm{C} / \mathrm{N}$ ratio) versus water runoff in the Leyre River. Only significant carbon parameter/runoff linear regressions are given $(p \leq 0.001)$
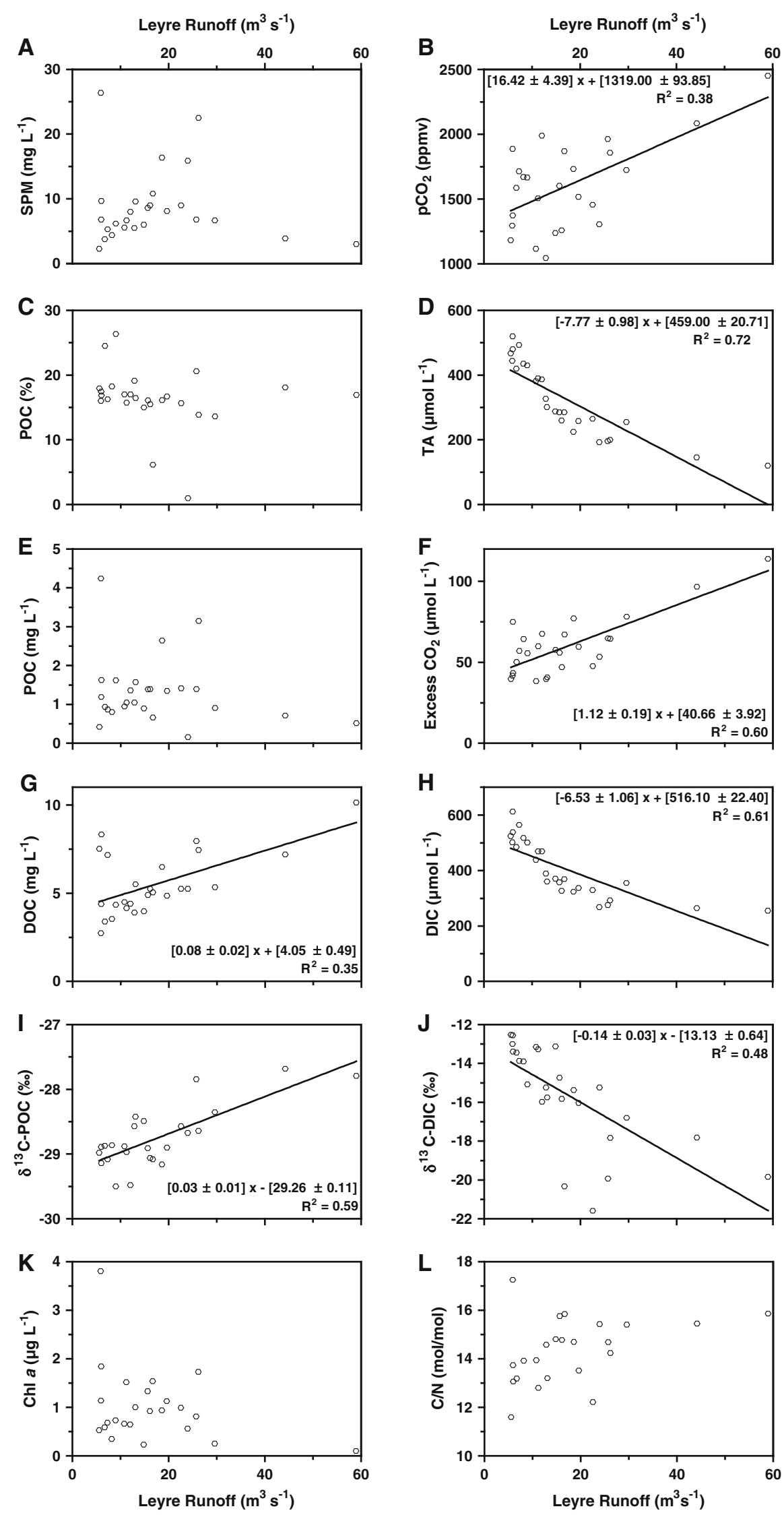

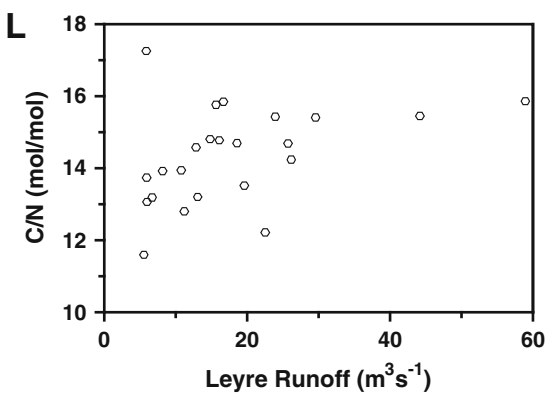




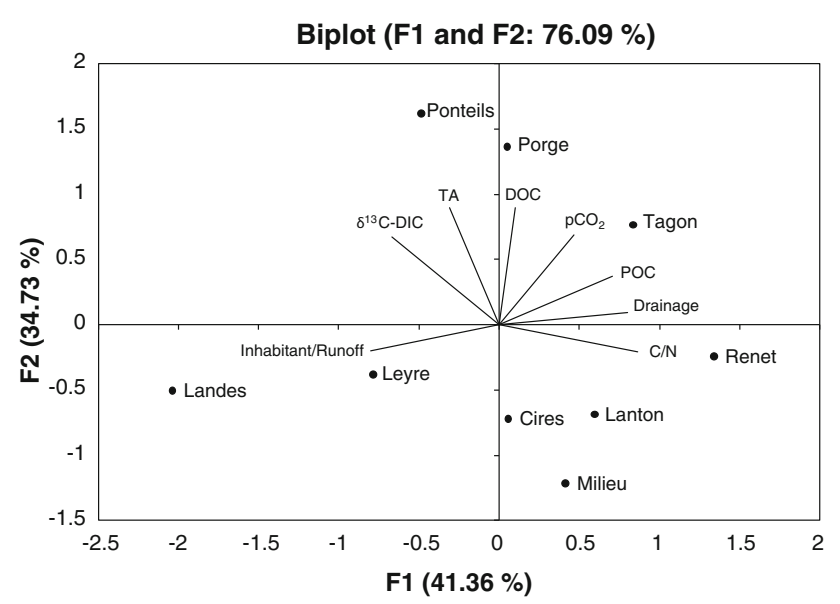

Fig. 5 Loadings plot of the principal component analysis (PCA) total variance percentage $=76.09 \%$. The graph shows the distribution of the nine sampled watercourses, nine observations functions to the eight measured factors ( 8 variables) as well as the correlations between the variables. Only eight variables were used here, as the redundancy of several variables hid the total explained variance. Six of these variables represent the measured parameters showing the greatest variations throughout the year $\left(\delta^{13} \mathrm{C}\right.$-DIC, TA, DOC, $p \mathrm{CO}_{2}$, $\mathrm{POC}$ and $\mathrm{C} / \mathrm{N}$ ratio), and two represent characteristics of river watersheds (inhabitant/runoff ratio and drainage): the inhabitant/ runoff ratio (inhab $\mathrm{m}^{-3} \mathrm{~s}$ ), stable isotope ${ }^{13} \mathrm{C}$ of DIC $\left(\delta^{13} \mathrm{C}-\mathrm{DIC}, \%\right.$ ), total alkalinity (TA, $\left.\mu \mathrm{mol} \mathrm{L}{ }^{-1}\right)$, DOC $\left(\mathrm{mg} \mathrm{L}^{-1}\right), p \mathrm{CO}_{2}$ (ppmv), POC $\left(\mathrm{mg} \mathrm{L}^{-1}\right)$, drainage $\left(\mathrm{L} \mathrm{s}^{-1} \mathrm{~km}^{-2}\right)$ and molar $\mathrm{C} / \mathrm{N}$ ratio. Variables that are situated along the same directional axis correlate positively with each other (TA/ $\delta{ }^{13} \mathrm{C}$-DIC, POC/drainage); variables that are situated at opposite ends of the plot correlate negatively with each other (e.g., $\mathrm{POC} /$ inhabitant/runoff, $\mathrm{C} / \mathrm{N} / \delta^{13} \mathrm{C}$-DIC); variables that are situated in the centre of the plot are poorly correlated and are poor predictors. The horizontal axis explains $41.36 \%$ of the variability and the vertical axis, $34.73 \%$; thus, the representation of the variables on these two axes is of good quality

increased in spring to reach maximum values during the summer and autumn, up to $10,000 \mathrm{ppmv}$ in the Ponteils stream (Fig. 3a-c). In the Leyre River only, an opposite $p \mathrm{CO}_{2}$ pattern was noticed with higher values (around $2,000 \mathrm{ppmv}$ ) in winter/spring and lower values (around $1,000 \mathrm{ppmv}$ ) in summer/autumn, although the $p \mathrm{CO}_{2}$ generally remained low over the annual cycle. The TA in the nine watercourses also followed to a lesser extent this former seasonal trend with the lowest values (approximately $100 \mu \mathrm{mol} \mathrm{L}^{-1}$ ) measured during the winter months and the highest values reaching close to $1,000 \mu \mathrm{mol} \mathrm{L}^{-1}$ in some watercourses during the summer months (for instance, in the Ponteils and Tagon streams). The excess $\mathrm{CO}_{2}$ (Fig. 3g-i) reflected this seasonal pattern, with minima in winter (near $100 \mu \mathrm{mol} \mathrm{L}^{-1}$ in the Landes canal) and maxima in the summer/autumn periods (nearly $500 \mu \mathrm{mol} \mathrm{L}^{-1}$ in the Ponteils stream).

Seasonality of carbon concentrations, particularly in the inorganic form, could be quantitatively related to the hydrological cycle in the Leyre River, where river discharges were available during the sampling period
(Fig. 4). No clear seasonal patterns linked to water runoff were measured in SPM and POC concentrations (and \%) (Fig. 4a, c, e). However, a significant increase in DOC concentrations with runoff ( $p=0.0015)$ was noticed and higher values were also measured for runoffs above $15 \mathrm{~m}^{3} \mathrm{~s}^{-1}$ (matching with winter, spring and late autumn seasons) than below $15 \mathrm{~m}^{3} \mathrm{~s}^{-1}$ (matching with summer, autumn and start of winter) with $6.3 \pm 1.6$ and $4.8 \pm 1.7 \mathrm{mg} \mathrm{L}^{-1}$, respectively $(p=0.0145$, MannWhitney test; Fig. $4 \mathrm{~g})$. Similarly, a significant increase in $\delta^{13} \mathrm{C}$-POC values was observed in this river $(p<0.0001)$. Contrary to organic carbon parameters, all of the DIC parameters showed a clear and significant correlation with water runoff (Fig. 4). DIC and TA concentrations decreased, whereas $p \mathrm{CO}_{2}$ and excess $\mathrm{CO}_{2}$ increased with increasing runoff (Fig. $4 \mathrm{~b}, \mathrm{~d}, \mathrm{f}, \mathrm{h}$ ). DIC concentrations of $481.5 \pm 72.7$ and $312.8 \pm 40 \mu \mathrm{mol} \mathrm{L}^{-1}$ for runoffs below and above $15 \mathrm{~m}^{3} \mathrm{~s}^{-1}$, respectively, were measured $(p<0.0001)$. A significant difference in TA concentrations was also observed between runoffs below and above $15 \mathrm{~m}^{3} \mathrm{~s}^{-1}$, i.e. $411.6 \pm 70.6$ and $224.0 \pm 53.7 \mu \mathrm{mol} \mathrm{L}{ }^{-1}$, respectively $(p<0.0001)$. On the contrary, the excess $\mathrm{CO}_{2}$ concentrations (Fig. 4f) showed significantly higher concentrations for runoffs above than below $15 \mathrm{~m}^{3} \mathrm{~s}^{-1}$ $\left(68.9 \pm 20.0\right.$ and $52.2 \pm 12.0 \mu \mathrm{mol} \mathrm{L}{ }^{-1}$, respectively, $p=0.0221)$. Finally, lower values of $\delta^{13} \mathrm{C}$-DIC were measured at higher runoffs $(-17.6 \pm 2.3 \%)$ than at lower runoffs $(-13.9 \pm 1.2)(p<0.0001)$ as illustrated by the significant decrease of $\delta^{13} \mathrm{C}$-DIC $(p<0.001$, Fig. $4 \mathrm{j})$.

\section{Differences in carbon concentrations and characteristics} among the Arcachon lagoon watershed watercourses

In spite of the common characteristic of the carbon parameters previously shown, differences between the nine watercourses were investigated by performing a principal component analysis (PCA; Fig. 5). First, an important contrast was observed in the very low values of $\delta^{13} \mathrm{C}$-DIC (below $-18 \%$ ), low TA (in general below $250 \mu \mathrm{mol} \mathrm{L}{ }^{-1}$ ) and very high $\mathrm{C} / \mathrm{N}$ ratios (above $17 \mathrm{~mol} \mathrm{~mol}^{-1}$ ) measured in the Cirès, Renet, Lanton, Milieu and Tagon watercourses as compared to the other watercourses. On the contrary, in the four other watercourses, i.e., the Porge, Ponteils, Leyre and Landes, the $\delta^{13} \mathrm{C}$-DIC values were higher, with values generally above $-15 \%$; the TA values were also higher than the former four rivers, with values typically above $300 \mu \mathrm{mol} \mathrm{L}{ }^{-1}$. Another contrast was observed in the Ponteils, Porge, Tagon and Renet watercourses, where DOC and $p \mathrm{CO}_{2}$ were particularly high in comparison to the others. Finally, high inhabitant/runoff ratios and low drainage values, correlated with low POC concentrations, differentiated the Leyre River and Landes canal from the other watercourses. 
Table 4 Watershed carbon export and export rates (TOC: POC + DOC and DIC: excess $\mathrm{CO}_{2}+\mathrm{DIC}_{\text {equilibrium }}+\mathrm{CO}_{2}$ degassing); carbon exports in $\mathrm{t} \mathrm{C}$ year $^{-1}$ (bold) and carbon export rates in $\mathrm{t} \mathrm{C} \mathrm{km}^{-2}$ year $^{-1}$ (italic)

\begin{tabular}{|c|c|c|c|c|c|c|c|c|}
\hline & \multirow{2}{*}{$\begin{array}{l}\text { Total } \\
(\text { TOC + DIC })\end{array}$} & \multicolumn{3}{|c|}{ Organic carbon } & \multicolumn{4}{|c|}{ Inorganic carbon } \\
\hline & & TOC & POC & DOC & DIC & Excess $\mathrm{CO}_{2}$ & $\mathrm{DIC}_{\text {equilibrium }}$ & $\mathrm{CO}_{2}$ degassing \\
\hline & $C$ export & & & & & & & $C$ degassing \\
\hline \multirow[t]{2}{*}{ Porge } & 2609 & 1658 & 306 & 1352 & 951 & 226 & 554 & $171^{\mathrm{a}}$ \\
\hline & 19.0 & 7.5 & 1.4 & 6.1 & 11.5 & 1.0 & 2.5 & $0.8^{\mathrm{a}}$ \\
\hline \multirow[t]{2}{*}{ Cirès } & 608 & 149 & 25 & 124 & 459 & 47 & 50 & 362 \\
\hline & 12.5 & 3.1 & 0.5 & 2.5 & 9.4 & 1.0 & 1.0 & 7.4 \\
\hline \multirow[t]{2}{*}{ Renet } & 603 & 144 & 29 & 115 & 459 & 56 & 55 & 348 \\
\hline & 33.7 & 8.1 & 1.6 & 6.4 & 25.6 & 3.1 & 3.1 & 19.4 \\
\hline \multirow[t]{2}{*}{ Lanton } & 197 & 63 & 15 & 48 & 134 & 15 & 20 & 99 \\
\hline & 5.3 & 1.7 & 0.4 & 1.3 & 3.6 & 0.4 & 0.5 & 2.7 \\
\hline \multirow[t]{2}{*}{ Milieu } & 276 & 128 & 35 & 93 & 148 & 26 & 28 & 94 \\
\hline & 12.9 & 6.0 & 1.6 & 4.4 & 6.9 & 1.2 & 1.3 & 4.4 \\
\hline \multirow[t]{2}{*}{ Ponteils } & 233 & 66 & 9 & 57 & 167 & 23 & 36 & $108^{\mathrm{a}}$ \\
\hline & 9.9 & 2.8 & 0.4 & 2.4 & 7.1 & 1.0 & 1.5 & $4.6^{\mathrm{a}}$ \\
\hline \multirow[t]{2}{*}{ Tagon } & 660 & 275 & 44 & 231 & 385 & 56 & 87 & 242 \\
\hline & 22.3 & 9.3 & 1.5 & 7.8 & 13 & 1.9 & 2.9 & 8.2 \\
\hline \multirow[t]{2}{*}{ Leyre } & 10,446 & 4096 & 667 & 3429 & 6350 & 470 & 1985 & 3895 \\
\hline & 4.8 & 1.9 & 0.3 & 1.6 & 2.9 & 0.2 & 0.9 & 1.8 \\
\hline \multirow[t]{2}{*}{ Landes } & 238 & 97 & 12 & 85 & 141 & 16 & 68 & $57^{\mathrm{a}}$ \\
\hline & 2.0 & 0.8 & 0.1 & 0.7 & 1.2 & 0.1 & 0.6 & $0.5^{\mathrm{a}}$ \\
\hline Total $\left(\mathrm{t} \mathrm{C}\right.$ year $\left.{ }^{-1}\right)$ & 15,870 & 6676 & 1142 & 5534 & 9194 & 935 & 2883 & 5376 \\
\hline Total $\left(\mathrm{t} \mathrm{C} \mathrm{km}^{-2}\right.$ year $\left.^{-1}\right)$ & 6.0 & 2.5 & 0.4 & 2.1 & 3.4 & 0.3 & 1.1 & 2 \\
\hline Percentage $(\%)$ & 100 & 42 & 7 & 35 & 58 & 6 & 18 & 34 \\
\hline
\end{tabular}

The $\mathrm{CO}_{2}$ degassing was calculated using the StreamCO 2 -DEGAS model, based on the $p \mathrm{CO}_{2}$, total alkalinity and $\delta^{13} \mathrm{C}$-DIC (Polsenaere and Abril 2012)

${ }^{\text {a }} \mathrm{CO}_{2}$ degassing for the Porge, Ponteils and the Landes watercourses were estimated using $K_{600}$ values that were set to 5,10 and $5 \mathrm{~cm} \mathrm{~h}^{-1}$, respectively. DIC equilibrium is computed as a theoretical DIC concentration in a river at atmospheric equilibrium (Abril et al. 2000). The total carbon export rate was computed as the sum of the nine carbon exports, i.e. the total carbon export (in $\mathrm{C}$ year ${ }^{-1}$ ) divided by the total catchment surface $\left(2656.5 \mathrm{~km}^{2}\right.$, Table 1). Percentages correspond to the proportion of each carbon form within the total carbon export rate of the Arcachon lagoon watershed

Carbon exports and export rates from the Arcachon lagoon watershed

The total carbon export from the entered Arcachon lagoon watershed was estimated at $15,870 \mathrm{tC}^{-1} \mathrm{yer}^{-1}$; equivalent to a carbon export rate of $6.0 \mathrm{t} \mathrm{C} \mathrm{km}^{-2}$ year $^{-1}$, including a $\mathrm{CO}_{2}$ degassing to the atmosphere of $2.0 \mathrm{t} \mathrm{C} \mathrm{km}^{-2}$ year $^{-1}$ (Table 4). The Leyre River accounted for more than $65 \%$ of this total carbon export (Table 4). Individual carbon export rates for subcatchments varied strongly, between $2.0 \mathrm{t} \mathrm{C} \mathrm{km}^{-2}$ year $^{-1}$ for Landes canal and $33.7 \mathrm{t} \mathrm{C}$ $\mathrm{km}^{-2}$ year $^{-1}$ for Renet stream. The contributions of each carbon species to the total export from the catchment were $7 \%$ for POC, $35 \%$ for DOC and $58 \%$ for DIC, the latter being partitioned into $6 \%$ of excess $\mathrm{CO}_{2}$ transported laterally, $18 \%$ of DIC at the equilibrium with the atmosphere, and $34 \%$ degassed as $\mathrm{CO}_{2}$ to the atmosphere along the watercourses (Table 4). The total POC export rate was $0.4 \mathrm{t} \mathrm{C} \mathrm{km}^{-2}$ year $^{-1}$ and ranged between $0.1 \mathrm{t} \mathrm{C} \mathrm{km}^{-2}$ year $^{-1}$ in Landes canal and $1.6 \mathrm{t} \mathrm{C}$ $\mathrm{km}^{-2}$ year $^{-1}$ in Renet and Milieu streams. The total DOC export rate was $2.1 \mathrm{t} \mathrm{C} \mathrm{km}^{-2}$ year $^{-1}$, with a minimum of 0.7 in the Landes canal and a maximum of $7.8 \mathrm{t} \mathrm{C} \mathrm{km}^{-2}$ year $^{-1}$ in Tagon stream. The total DIC export rate was $3.4 \mathrm{t} \mathrm{C} \mathrm{km}^{-2}$ year $^{-1}$ and ranged between $1.2 \mathrm{t} \mathrm{C} \mathrm{km}^{-2}$ year $^{-1}$ in Landes canal to $25.6 \mathrm{t} \mathrm{C}$ $\mathrm{km}^{-2}$ year $^{-1}$ in Renet stream. Lateral transport of excess $\mathrm{CO}_{2}$ for the whole catchment account for $6 \%$ of the total export, similar to the POC export rate to the lagoon. Finally, among the $6.0 \mathrm{t} \mathrm{C} \mathrm{km}^{-2}$ year $^{-1}$ exported from land, $2.0 \mathrm{t} \mathrm{C} \mathrm{km}^{-2}$ year $^{-1}$ escaped to the atmosphere along watercourses and did not reach the lagoon, a quantity similar to the DOC export. Degassing rates (expressed per unit area of the catchment) ranged from $0.5 \mathrm{t} \mathrm{C}$ 
$\mathrm{km}^{-2}$ year $^{-1}$ in Landes canal to $19.4 \mathrm{t} \mathrm{C} \mathrm{km}^{-2}$ year $^{-1}$ in Renet stream (Table 4).

\section{Discussion}

The nine watercourses sampled around the Arcachon lagoon showed relatively homogeneous carbon characteristics due to the relative uniformity of the catchment: low SPM and POC concentrations associated with a high contribution of POC within the SPM; a low Chl $a$ concentration, high $\mathrm{POC} / \mathrm{SPM}$ and molar $\mathrm{C} / \mathrm{N}$ ratios, very low values of $\delta^{13} \mathrm{C}$-POC; a high DOC concentration and a low TA that was associated with a high $p \mathrm{CO}_{2}$. However, significant seasonal patterns, linked to the water runoff and differences from one watercourse to another were noticed, in particular for inorganic carbon parameters. Variations were also observed in terms of carbon exports (and rates) from the nine watercourses with different relative contributions of each carbon form within the whole Arcachon lagoon catchment carbon budget.

Origin of carbon among the watercourses flowing to the Arcachon lagoon

Our study reveals an almost complete terrestrial origin of POC in the Arcachon catchment. POC here is allochthonous and originates from soil and terrestrial $\mathrm{C}_{3}$ plants, with typical molar $\mathrm{C} / \mathrm{N}$ ratios higher than 12 (Bordovskiy 1965), and $\delta^{13} \mathrm{C}$-POC values of -27 to $-30 \%$ (Mook and Tan 1991). In addition, low Chl $a$ concentration and high POC/ Chl $a$ ratios indicate a low contribution of phytoplankton to POC contrary to eutrophic rivers for instance (Abril et al. 2002; Neal et al. 2006). Indeed, phytoplankton generally exhibits a POC/Chl $a$ ratio ranging between 20 and 140, and it is generally accepted that phytoplankton-dominated $\mathrm{POM}$ has a POC/Chl $a$ ratio that is lower than 200 (Savoye et al. 2003). Photosynthesis is likely limited by hydrological factors as shown in the rivers of eastern England by Neal et al. (2006). Additionally, these waters with low pH values and low inorganic nutrient concentrations (Canton et al. 2012) could limit phytoplankton growth, as has been shown in peatland watercourses (Greenwood and Lowe 2006). The extremely negative $\delta^{13} \mathrm{C}$-DIC values (Table 3 ; Fig. $3 \mathrm{~m}-\mathrm{o}$ ) also confirms a weak instream net photosynthesis in these types of watercourses, as already shown in other watercourses, such as river-tributary stream systems (Atekwana and Krishnamurthy 1998).

The ubiquity of acidic podzols with high organic carbon content (Jolivet et al. 2007) lead to relatively high concentrations of DOC in the nine sampled watercourses (Table 2; Fig. 2p-r). This specificity has also been reported in boreal wetlands and temperate peatlands (Ågren et al.
2007; Billett et al. 2006). Aitkenhead et al. (1999) showed that DOC fluxes appear to strongly reflect the size of the soil organic carbon pool in the catchment. Firstly, the DOC found in the Arcachon watercourses could partly originate from high molecular weight compounds such as humic and fulvic acids. Indeed, although the podzolisation process typically results in the net retention of DOC, mature podzols continuously release DOC to rivers (Aitkenhead and McDowell 2000). This DOC background found in river waters is relatively recalcitrant (Vestin et al. 2008). Secondly, high DOC concentrations as decomposable compounds might probably be released for instance from the hyporheic zone. This DOC is derived partly from the degradation of biota and from roots and mycorrhiza exudates (Lundström et al. 2000; Van Hees et al. 2005). After hyporheic transport, this DOC constitutes an appropriate substrate for bacterial mineralisation, leading in turn to large amounts of $\mathrm{CO}_{2}$ (Schindler and Krabbenhoft 1998; Sobek et al. 2005). This assumption is reinforced by the significant positive correlations observed between DOC concentrations and $p \mathrm{CO}_{2}$ values observed in some of the watercourses as the Lanton, Ponteils, Tagon streams and Leyre River (Fig. 6a). In the Arcachon lagoon catchment, all of these DOC origins and processes are probably involved but further specific analysis using stable isotopes $\left(\delta^{13} \mathrm{C}\right.$-DOC) should be done to determine the composition of DOC in the Arcachon catchment.

The Arcachon lagoon watercourses represented a source of $\mathrm{CO}_{2}$ to the atmosphere throughout the year; water $p \mathrm{CO}_{2}$ were always oversaturated and never reached equilibrium with the atmosphere as shown in many organic-rich natural waters (Billett and Moore 2008). In small watercourses with short water residence times, water chemistry is strongly driven by terrestrial-aquatic connections (Jones and Mulholland 1998; Jones et al. 2003). Consequently, the $\mathrm{CO}_{2}$ that is attributable to instream respiration is typically minor and the major source of $\mathrm{CO}_{2}$ originates from root and bacterial respiration in soils followed by discharge of $\mathrm{CO}_{2}$ enriched groundwater (Castelle and Galloway 1990; Kling et al. 1992; Johnson et al. 2008). This outstream $\mathrm{CO}_{2}$ production probably prevails at our study sites, as already been observed in many other small head watercourses in temperate, tropical and boreal systems (Jones et al. 2003; Billett and Moore 2008; Johnson et al. 2008; Rantakari et al. 2010). The overall very negative $\delta^{13} \mathrm{C}$-DIC values (Table 3; Fig. $3 \mathrm{~m}-\mathrm{o}$ ) confirm that $\mathrm{CO}_{2}$ production is fuelled by terrestrial carbon. Indeed, in a system where the soil $\mathrm{CO}_{2}$ is primarily derived from the decomposition of $\mathrm{C}_{3}$ plant organic matter, the $\mathrm{CO}_{2}$ produced has a $\delta^{13} \mathrm{C}$ value close to the initial substrate, with means of -30 to $-24 \%$ (Vogel 1993). As $\mathrm{CO}_{2}$ progressively degasses along the watercourse, $\delta^{13} \mathrm{C}$-DIC becomes less negative due to water-air isotopic equilibration (Polsenaere and Abril 
Fig. 6 Carbon cross-parameter plots for the nine sampled watercourses. a The partial pressure of $\mathrm{CO}_{2}$ versus the dissolved organic carbon $\left(p \mathrm{CO}_{2} / \mathrm{DOC}\right), \mathbf{b}$ the stable isotope of DIC versus the partial pressure of $\mathrm{CO}_{2}\left(\delta^{13} \mathrm{C}\right.$-DIC/ $\left.p \mathrm{CO}_{2}\right)$ and $\mathbf{c}$ the stable isotope of DIC versus the total alkalinity $\left(\delta^{13} \mathrm{C}\right.$-DIC/TA). Only data from rivers where significant correlations were found are shown $(p<0.05)$
A
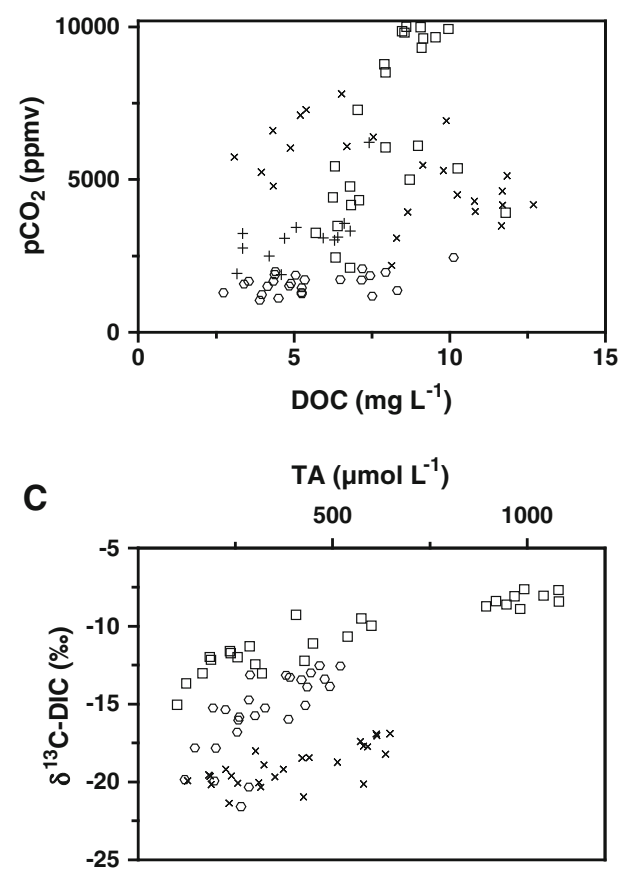

B

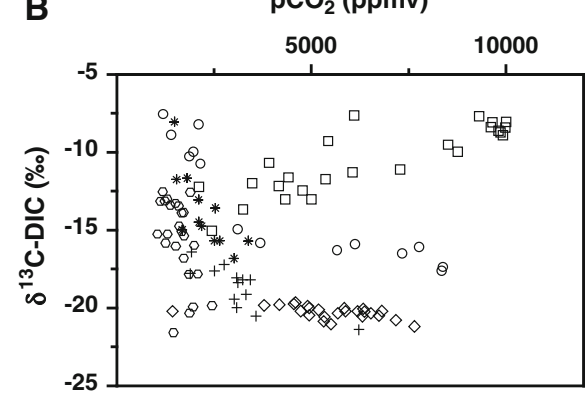

2012). This is one of the main reasons for the significant negative correlations between $\delta^{13} \mathrm{C}$-DIC and $p \mathrm{CO}_{2}$ observed in Renet and Lanton streams, Leyre River and both canals (Fig. 6b).

Another reason for the negative $\delta^{13} \mathrm{C}$-DIC values in the study watersheds is the predominance of silicate rock weathering over carbonate rock weathering, consistent with the low TA values (Table 3 ). In monolithic watersheds, Meybeck (1987) reported a TA value of $125 \mu \mathrm{mol} \mathrm{L}^{-1}$ for silicate watersheds, and of $3,195 \mu \mathrm{mol} \mathrm{L}^{-1}$ for carbonate watersheds. If we assume these concentrations as representative of these two types of rock weathering, we can calculate that the contribution of carbonate weathering to TA does not exceed $6 \%$ on average in the nine watercourses $(0-14 \%$ in the Milieu and Ponteils streams, respectively). However, despite these modest contributions to TA, the effect of carbonate weathering on the isotope signature of the $\delta^{13} \mathrm{C}$-DIC source was significant. In the Ponteils and Tagon streams and the Leyre River, we observed a significant positive correlation between $\delta^{13} \mathrm{C}$ DIC and TA values (Fig. 6c). This is likely explained by the greater presence of carbonates in these three watersheds. The Ponteils stream was the only site where $\delta^{13} \mathrm{C}$ DIC was positively correlated with $p \mathrm{CO}_{2}$ and TA (Fig. 6b, c), with higher values occurring in summer (Fig. 3a, d and $\mathrm{m})$. This stream hosts a landfill site, which is known to greatly affect the composition of groundwaters (Canton et al. 2010). We can thus suspect concomitant TA and $\mathrm{CO}_{2}$ inputs from this anthropogenic source, resulting to $\delta^{13} \mathrm{C}$ -
DIC values close to those found in a carbonate-dominated watershed (Barth et al. 2003). Finally, in the Porge canal where tidal intrusion occurs, a contribution of marine DIC waters from the lagoon, with a $\delta^{13} \mathrm{C}$-DIC value of $-0.62 \%$ on average (Polsenaere, unpublished data), could explain the occasional high values of $\delta^{13} \mathrm{C}$-DIC and TA (Fig. 3d, m).

Hydrology as the main driver of carbon concentrations and characteristics in small watercourses

Temporal patterns in all watercourses (Figs. 2, 3) and concentration versus discharge relationships in the Leyre River (Fig. 4) reveal distinct origins and transport mechanisms for organic and inorganic carbon. Indeed, carbon concentrations are closely related to water runoffs as shown in many other watercourse systems (Meybeck 1982; Hope et al. 1997; Atekwana and Krishnamurthy 1998; Agren et al. 2007). A specificity observed in the nine sampled small watercourses is that organic carbon parameters generally show a relative temporal stability throughout the year due to the predominance of a constant terrestrial source. Despite this constant source, POC and particularly DOC are mostly transported in a pulsated mode during periods of high discharge in autumn or winter as observed in the Leyre River (Figs. 4e, g). This was consistent with results in other small forested headwater catchments (Rantakari et al. 2010). Preferencial superficial flushing transport for DOC has also been reported in many 
other temperate watercourses (Tranvik and Jansson 2002; Mulholland 2003); it generally leads in turn to a dominant soil and plant organic matter source of riverine DOC (Mantoura and Woodward 1983; Aitkenhead et al. 1999).

DIC parameters showed strong seasonal contrasts, linked to patterns both in $\mathrm{CO}_{2}$ production and transfer through the soil, groundwaters, rivers and the atmosphere, and in rock weathering pathways. Indeed, DIC composition and flux can vary accordingly to the soil horizons that are affected by transport to surface waters (Michalzik et al. 2001). Such DIC transport implies important groundwatersurfacewater connections as in the Arcachon lagoon watershed and in other river-tributary stream systems (Atekwana and Krishnamurthy 1998). In these types of watersheds, DIC parameters in watercourses are controlled by two processes with opposite effects. During high discharge periods (autumn/winter), the streamflow is a mixture of surface runoff, subsurface or hypodermic runoff and groundwater flow (Probst 1985), which results in a decrease in DIC or TA concentrations (Fig. 4h, d). On the contrary, during low flow periods (summer/autumn), DIC or TA concentrations increase with increasing groundwater discharge (Hynes 1983). During low runoff, groundwater residence time is also increased and rock-weathering products accumulate; consequently, waters are enriched in DIC (Jones and Mulholland 1998).

The decrease in DIC concentrations with runoff found in the Leyre River was also observed in a similar temperate system, i.e. the Kalamazoo River (Southwest Michigan) (Atekwana and Krishnamurthy 1998). However, in contrast to our study watercourses, $p \mathrm{CO}_{2}$ increased with runoff in the Leyre river with slightly higher values during winter periods (Figs. 3c, 4b), which suggests a different $\mathrm{CO}_{2}$ production and transport pattern. Flooding of the Leyre River in winter apparently increased heterotrophic metabolism of terrestrial organic matter, at the edge of the river or in the river itself as reported in another forested catchment by Finlay (2003). The negative correlation between $\delta^{13} \mathrm{C}$-DIC and runoff (Fig. $4 \mathrm{j}$ ) is also consistent with the idea of a higher soil and $\mathrm{C}_{3}$ litter mineralisation rate during flood events, combined with carbonate weathering in groundwater in summer. In contrast, in small streams, large $\mathrm{CO}_{2}$ inputs from the soil and groundwater mostly occur during low-flow periods (Fig. 3a-c) and are also enhanced by a longer residence time of the water in soils and groundwater. Amiotte-Suchet et al. (1999) suggested that enhanced soil organic matter oxidation in summer induces high $p \mathrm{CO}_{2}$ in soils and prevents atmospheric $\mathrm{CO}_{2}$ from penetrating the soil. This is the reason why in all of the streams except the anthropogically impacted Ponteils stream, $\delta^{13} \mathrm{C}$-DIC was negatively correlated with $p \mathrm{CO}_{2}$ (Fig. 6b). Similarly, excess $\mathrm{CO}_{2}$ levels measured in the Arcachon streams, especially during summer, were consistently larger than those measured in larger watercourses as the Leyre River. This result is in agreement with studies by Genereux and Hemond (1992) and Butman and Raymond (2011), who showed that small streams tend to emit large amounts of $\mathrm{CO}_{2}$ per unit area. In contrast, in the winter and early spring, $p \mathrm{CO}_{2}$ in these watercourses decreases due to the predominance of superficial flow, a minor contribution of groundwater to surface water and a lower water residence time in the soils and groundwater. As a consequence, this leads to lower amounts of $\mathrm{CO}_{2}$ emitted to the atmosphere during the winter season.

Carbon export from the Arcachon lagoon watershed compared to temperate and global systems

We calculated the export of carbon from individual watersheds, including POC, DOC, DIC (at the atmospheric equilibrium and as excess $\mathrm{CO}_{2}$ ) and $\mathrm{CO}_{2}$ degassing along watercourses (Table 4), as well as the seasonal variations in the contribution of each term (Fig. 7). $\mathrm{CO}_{2}$ degassing was calculated using an original modelling approach based on DIC isotopic equilibration with the atmosphere (Polsenaere and Abril 2012). Gas transfer velocities obtained with this model ranged between 2 and $30 \mathrm{~cm} \mathrm{~h}^{-1}$, consistent with those reported in other headwaters between 10 and $75 \mathrm{~cm} \mathrm{~h}^{-1}$ (e.g. Butman and Raymond 2011). We observed large seasonal variations in the proportion of the different carbon species exported from the catchment throughout the year (Fig. 7). As DOC concentrations showed moderate seasonal changes, DOC export was driven by water discharge and was maximal in winter; in contrast, as DIC concentrations increased in summer, DIC export remained more stable throughout the year. As a result, the ratio between degassing and lateral transport to the Arcachon lagoon varied between 0.1 in winter and 1.6 in summer (Fig. 7).

On an annual basis, the relative proportions of each carbon species exported from the watershed of the Arcachon lagoon (Table 4) are in good agreement with those reported for temperate rivers (Meybeck 1993). A global data compilation by Alvarez-Cobelas et al. (2012) shows similar values for organic carbon export rates between 1.8 and $10.0 \mathrm{t} \mathrm{C} \mathrm{km}^{-2}$ year $^{-1}$ in temperate catchments; our data are also close to values reported by Abril et al. (2000) in other temperate rivers in Belgium (Table 5). However, some local specificities appeared at our study sites due to the dominance of podzols (Table 5). Indeed, organic carbon was exported predominantly in the form of DOC; this DOC export rate was higher than in a temperate forested catchment in central Japan with values ranged from 0.8 to $2.6 \mathrm{t} \mathrm{C} \mathrm{km}^{-2}$ year $^{-1}$ (Okazaki 2001; Kawasaki 2002). Similar DOC exports were also observed in temperate rivers of England and Wales (Worrall et al. 2007). 
Fig. 7 Seasonal variations in the Arcachon lagoon catchment carbon export rates. a The monthly river discharges to the lagoon, with the part represented by the Leyre River, b comparison of the mean carbon export rate without $\mathrm{CO}_{2}$ degassing, and the mean $\mathrm{CO}_{2}$ degassing export rate (t C km ${ }^{-2}$ year $^{-1}$ ); $\mathbf{c}$ the relative contribution (\%) of DIC export rates as $\mathrm{CO}_{2}$ degassing, excess $\mathrm{CO}_{2}$ and DIC at atmospheric equilibrium, and of dissolved organic carbon (DOC) and particulate organic carbon (POC) export rates to the mean carbon export and $\mathbf{d} \mathrm{CO}_{2}$ degassing export rate/carbon export rate without $\mathrm{CO}_{2}$ degassing ratio (degassing/ export*)
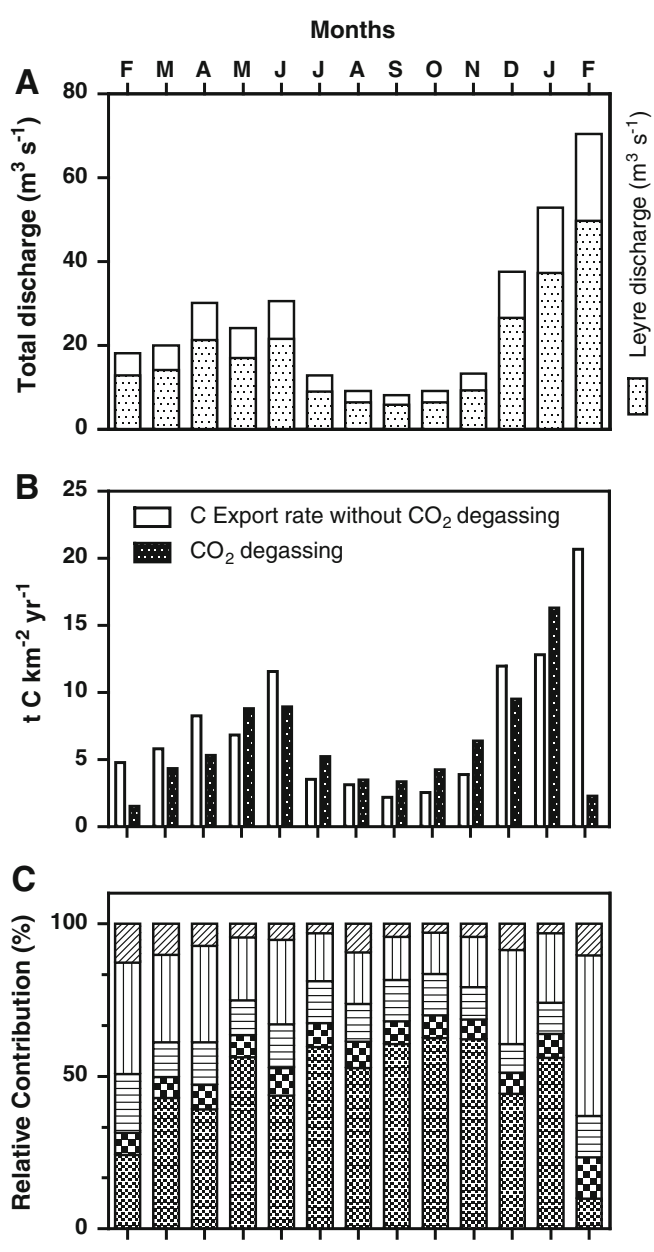

Q DIC Export rate as $\mathrm{CO}_{2}$ degassing

$\mathrm{ED}$ DIC Export rate as Excess $\mathrm{CO}_{2}$

$\exists$ DIC Export rate at atmospheric equilibrium

एس DOC Export rate

IID POC Export rate

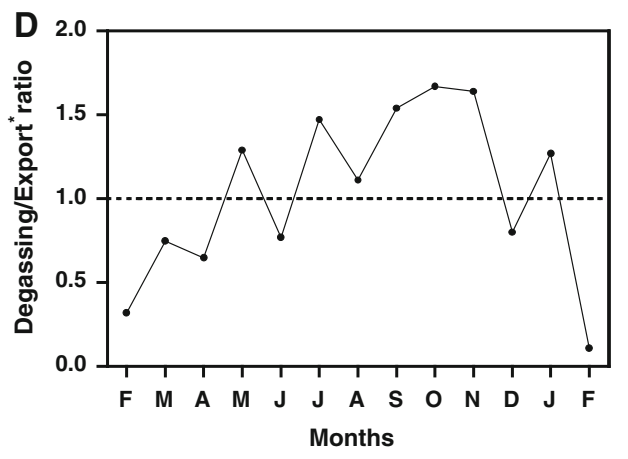

Globally, Alvarez-Cobelas et al. (2012) reported that DOC comprised on average $73 \%$ of TOC export, close to the $80 \%$ found in our study (Table 5). However, similar or even greater DOC export rates were measured in streams draining temperate peatlands, reaching more than $90 \%$ of the organic carbon export rate (Billett et al. 2004; Dawson et al. 2004). This suggests a similar control on DOC export by the magnitude of organic carbon stored in the soils of peats and podzols. In the Arcachon lagoon catchment, POC export rates were typical of lowland regions, with weak erosion that leads to relatively clear waters (Meybeck 1982, 1993). These rates were slightly below the range found by
Worrall et al. (2007) in the rivers of England and Wales or by Dawson et al. (2004) in the peatland streams of Scotland (Table 5).

In our temperate podzolized catchment, DIC accounted for $58 \%$ of the total carbon export rate. A similar dominant DIC export rate has been reported in the highly polluted Scheldt estuary (Abril et al. 2000). When compared to temperate peatlands, the Arcachon lagoon catchment has similar DIC export but lower organic carbon export rates. Also, export rates as excess $\mathrm{CO}_{2}$ were within the range of values found in rivers of England and Wales (Worrall et al. (2007) and in peatland streams (Dawson 
Table 5 Synthesis of carbon export rates from different catchment sizes and zones (temperate and global)

\begin{tabular}{|c|c|c|c|c|c|c|c|c|c|}
\hline Site characteristics & $\begin{array}{l}\text { Carbon } \\
\text { Export } \\
\text { rates }\end{array}$ & $\begin{array}{l}\text { TOC } \\
\text { Export }\end{array}$ & $\begin{array}{l}\text { POC } \\
\text { Export }\end{array}$ & $\begin{array}{l}\text { DOC } \\
\text { Export }\end{array}$ & $\begin{array}{l}\text { DIC } \\
\text { Export }\end{array}$ & $\begin{array}{l}\text { Excess } \\
\mathrm{CO}_{2} \\
\text { Export }\end{array}$ & $\begin{array}{l}\mathrm{DIC}_{\text {equilibrium }} \\
\text { Export }\end{array}$ & $\begin{array}{l}\mathrm{CO}_{2} \\
\text { degassing }\end{array}$ & References \\
\hline \multirow{2}{*}{$\begin{array}{l}\text { Temperate lowland rivers } \\
\text { (France) }\end{array}$} & 2.0-3.7 & $0.8-9.3$ & 0.1-1.6 & $0.7-7.8$ & $1.2-25.6$ & 0.1-3.1 & $0.5-3.1$ & $0.5-19.4$ & This study \\
\hline & & $36 \%$ & $7 \%$ & $29 \%$ & $21 \%$ & $8 \%$ & $13 \%$ & $43 \%$ & \\
\hline \multirow[t]{2}{*}{$\begin{array}{l}\text { Temperate rivers (England } \\
\text { and Wales) }\end{array}$} & 9.5-11.4 & $5.3-7.2$ & $1.9-2.6$ & $3.4-4.6$ & & 2.1-2.9 & & 4.2 & $\begin{array}{l}\text { Worrall et al. } \\
\text { (2007) }\end{array}$ \\
\hline & & $60 \%$ & $25 \%$ & $35 \%$ & & $24 \%$ & & $40 \%$ & \\
\hline \multirow[t]{2}{*}{$\begin{array}{l}\text { Impacted temperate rivers } \\
\text { (Belgium) }\end{array}$} & $8.6-38.2$ & $2.8-21.3$ & $2.2-17.4$ & $0.7-3.9$ & $5.7-16.8$ & $0.6-1.4$ & $5.2-15.5$ & & $\begin{array}{l}\text { Abril et al. } \\
\text { (2000) }\end{array}$ \\
\hline & & $36 \%$ & $27 \%$ & $9 \%$ & $61 \%$ & $6 \%$ & $55 \%$ & & \\
\hline $\begin{array}{l}\text { Temperate lowland } \\
\text { peatland streams } \\
\text { (Scotland) }\end{array}$ & $30.4 \pm 5.7$ & $\begin{array}{l}\mathbf{2 8 . 3} \pm \mathbf{5 . 7} \\
93 \%\end{array}$ & & & $\begin{array}{l}\mathbf{2 . 1} \pm \mathbf{0 . 5} \\
7 \%\end{array}$ & & & 4.6 & $\begin{array}{l}\text { Billett et al. } \\
\text { (2004) }\end{array}$ \\
\hline \multirow[t]{2}{*}{$\begin{array}{l}\text { Temperate peatland } \\
\text { streams (NE Scotland) }\end{array}$} & 12.6-32.9 & 12.3-31.2 & $0.8-9.7$ & 11.5-21.5 & & $0.3-1.7$ & & & $\begin{array}{l}\text { Dawson et al. } \\
\text { (2004) }\end{array}$ \\
\hline & & $95 \%$ & $23 \%$ & $72 \%$ & & $5 \%$ & & & \\
\hline $\begin{array}{l}\text { Temperate streams and } \\
\text { rivers (US) }\end{array}$ & & & & & & & & $12.4 \pm 3$ & $\begin{array}{l}\text { Butman and } \\
\text { Raymond } \\
\text { (2011) }\end{array}$ \\
\hline $\begin{array}{l}\text { Temperate rivers } \\
\text { (worldwide) }\end{array}$ & & $1.8-10.0$ & $1.2-2.1$ & $0.8-5.7$ & & & & & $\begin{array}{l}\text { Alvarez-Cobelas } \\
\text { et al. (2012) }\end{array}$ \\
\hline $\begin{array}{l}\text { Temperate rivers and } \\
\text { streams }\end{array}$ & & & & & & & & $1.1-1.8$ & $\begin{array}{l}\text { Aufdenkampe } \\
\text { et al. (2011) }\end{array}$ \\
\hline Global rivers and lakes & & 3.4 & & & & & & $\begin{array}{l}2.5 \\
39 \%\end{array}$ & $\begin{array}{l}\text { Cole et al. } \\
\quad(2007)\end{array}$ \\
\hline Global with lakes & & & & & & & & $\begin{array}{l}10.4 \\
48 \%\end{array}$ & $\begin{array}{l}\text { Tranvik et al. } \\
\text { (2009) }\end{array}$ \\
\hline $\begin{array}{l}\text { Global with lakes and } \\
\text { wetlands }\end{array}$ & & 3.0 & & & & & & 24.5 & $\begin{array}{l}\text { Aufdenkampe } \\
\text { et al. (2011) }\end{array}$ \\
\hline
\end{tabular}

The relative importance of POC export, DOC export, DIC export (DIC at equilibrium and the excess of $\mathrm{CO}_{2}$ and $\mathrm{CO}_{2}$ degassing) to carbon budgets is shown. Values in bold are expressed in $\mathrm{t}_{\mathrm{km}}^{-2}$ year ${ }^{-1}$. The temperate (US and worldwide) and global carbon export rates have been obtained normalizing the carbon exports (in $\mathrm{Pg} \mathrm{C}_{\mathrm{Cear}}^{-1}$ ) found in the cited literature by the temperate (between $25^{\circ} \mathrm{N}$ and $50^{\circ} \mathrm{N}$ ) and the global land surface areas, respectively $\left(44.10^{6}\right.$ and $134.10^{6} \mathrm{~km}^{2}$, Aufdenkampe et al. 2011; Butman and Raymond 2011, supplementary information)

et al. 2004) (Table 5). In many studies, the portion of the DIC that is exported by river waters can largely be underestimated if the $\mathrm{CO}_{2}$ degassing to the atmosphere is not taken into account (Cole et al. 2007; Tranvik et al. 2009; Butman and Raymond 2011). In the Arcachon lagoon catchment, export as $\mathrm{CO}_{2}$ degassing accounts for $40-73 \%$ of the total carbon export and was on the same order as the TOC export rate (Table 5). The range estimated in this study is also in good agreement with the $\mathrm{CO}_{2}$ efflux value of $12.4 \pm 3 \mathrm{t} \mathrm{C} \mathrm{km}^{-2}$ year $^{-1}$ found by Butman and Raymond (2011) in temperate streams and rivers in United States (Table 5). Finally, it is interesting to observe that the relative proportion between $\mathrm{CO}_{2}$ degassing and TOC export in the study rivers were close to those reported at the global scale. Indeed, global TOC export by rivers to the ocean have been estimated at around
$3 \mathrm{t} \mathrm{C} \mathrm{km}^{-2}$ year ${ }^{-1}$ and $\mathrm{CO}_{2}$ outgassing by rivers and lakes has been estimated at 10.4 (Tranvik et al. 2009) and at $24.5 \mathrm{t} \mathrm{C} \mathrm{km}^{-2}$ year $^{-1}$ when accounting for wetlands (Aufdenkampe et al. 2011).

Significance in the regional forest and lagoon carbon budgets

The total loss of carbon from the watershed of $6 \mathrm{~g} \mathrm{C} \mathrm{m}^{-2}$ year $^{-1}$, with $2 \mathrm{~g} \mathrm{C} \mathrm{m}^{-2}$ year $^{-1}$ as $\mathrm{CO}_{2}$ degassing to the atmosphere, represents a very minor part of the carbon uptake by the forest inland. Indeed, the carbon fixation by the maritime pine forest of Landes Gascony is estimated to be $345 \mathrm{~g} \mathrm{C} \mathrm{m}^{-2}$ year $^{-1}$ on average from 1996 to 2006 (EUROFLUX site of the Bray, $44^{\circ} 43^{\prime} 33.24^{\prime \prime} \mathrm{N}, 0^{\circ} 46^{\prime} 33.72^{\prime \prime} \mathrm{W}$ ) (Loustau, personal communication). However, this total 
carbon loss through the watercourses becomes more significant in some special years, like the year 2002, when the carbon uptake was only $57 \mathrm{~g} \mathrm{C} \mathrm{m}^{-2}$ year $^{-1}$ (Jarosz et al. 2008). However, the Landes Gascony ecosystem seems to lose less carbon through the watershed compared to other similar ecosystems such as, for instance, northern peatlands (Billett et al. 2004). When considering the lagoon ecosystem, inputs from land by rivers and streams represent a flux of $10,494 \mathrm{t} \mathrm{C}$ year $^{-1}$ among which $6676 \mathrm{t} \mathrm{C}$ year $^{-1}$ is organic and $3818 \mathrm{t} \mathrm{C}$ year $^{-1}$ is inorganic. These fluxes are significant when compared, for instance, with primary production in the lagoon by the eelgrass Zostera noltii $\left(17,800 \mathrm{t} \mathrm{C}\right.$ year $^{-1}$; Auby and Labourg 1996) and phytoplankton (17,920 t C year $^{-1}$; Glé et al. 2008). However, Dang et al. (2009) have shown that riverine particulate organic matter $(1,142$ t $\mathrm{C}$ year $^{-1}$, Table 4 ) contributes modestly (less than $15 \%$ ) to the diet of primary consumers, such as clams in the Arcachon lagoon (below $15 \%$ ). Similarly, Dubois et al. (2011) have shown that terrestrial POC contributes less than $20 \%$ of the sediment organic matter (SOM) of the Arcachon lagoon. The riverine DOC, can potentially fuel the aquatic trophic chain through the microbial loop; however, its impact is probably limited due to the fast dilution of the freshwater with oceanic waters and the short flushing time of the lagoon with the tide. Similarly, riverine DIC inputs as excess $\mathrm{CO}_{2}$ is probably a very minor contributor of the $\mathrm{CO}_{2}$ degassing reported during emersion in the Arcachon lagoon (Polsenaere et al. 2012).

Acknowledgments We would like to express our thanks to Aurélia Mouret, Jonathan Deborde and Romain Chassagne who contributed to field sampling. This paper is a contribution to the PNEC (Programme National Environnement Côtier)-Littoral Atlantique and ANR PROTIDAL (Agence Nationale de la Recherche « Processus biogéochimiques transitoires de la zone intertidale ») projects.

\section{References}

Abril G, Etcheber H, Borges AV, Frankignoulle M (2000) Excess atmospheric carbon dioxide transported by rivers into the Scheldt Estuary. Comptes Rendus de l'Académie des Sciences, Série IIA 330:761-768

Abril G, Nogueira M, Etcheber H, Cabeçadas G, Lemaire E, Brogueira MJ (2002) Behaviour of organic carbon in nine contrasting European estuaries. Estuar Coast Shelf Sci 54: 241-262

Ågren A, Jansson M, Ivarsson H, Bishop K, Seibert J (2007) Seasonal and runoff-related changes in total organic carbon concentrations in the River Öre, Northern Sweden. Aquat Sci 70:21-29

Aitkenhead JA, McDowell WH (2000) Soil C:N ratio as a predictor of annual riverine DOC flux at local and global scales. Glob Biogeochem Cycles 14:127-138

Aitkenhead JA, Hope D, Billett MF (1999) The relationship between dissolved organic carbon in stream water and soil organic carbon pools at different spatial scales. Hydrol Process 13:1289-1302

Alvarez-Cobelas M, Angeler DG, Sánchez-Carrillo S, Almendros G (2012) A worldwide view of organic carbon export from catchments. Biogeochem 107:275-293
Amiotte-Suchet P, Aubert D, Probst JL, Gauthier-Lafaye F, Probst A, Andreux F, Viville D (1999) $\delta^{13} \mathrm{C}$ pattern of dissolved inorganic carbon in a small granitic catchment: the strengbach case study Vosges mountains, France. Chem Geol 159:129-145

Atekwana EA, Krishnamurthy RV (1998) Seasonal variations of dissolved inorganic carbon and $\delta^{13} \mathrm{C}$ of surface water: application of a modified gas evolution technique. J Hydrol 205:265-278

Auby I, Labourg PJ (1996) Seasonal dynamics of Zostera noltii Hornem in Bay of Arcachon France. J Sea Res 35:269-277

Auby I, Manaud F, Maurer D, Trut G (1994) Etude de la prolifération des algues vertes dans le bassin d'Arcachon. Rapport IFREMERCEMAGREF-SSA-SABARC, pp 1-163

Aufdenkampe AK, Mayorga E, Raymond PA, Melack JM, Doney SC, Alin SR, Aalto RE, Yoo K (2011) Riverine coupling of biogeochemical cycles between land, oceans, and atmosphere. Front Ecol Environ 9:53-60. doi:10.1890/100014

Barth JAC, Cronin AA, Dunlop J, Kalin RM (2003) Influence of carbonates on the riverine carbon cycle in an anthropogenically dominated catchment basin: evidence from major elements and stable carbon isotopes in the Lagan River N Ireland. Chem Geol 200:203-216

Bianchi TS, Filley T, Dria K, Hatcher PG (2004) Temporal variability in sources of dissolved organic carbon in the lower Mississippi river. Geochim Cosmochim Acta 5:959-967

Billett MF, Moore TR (2008) Supersaturation and evasion of $\mathrm{CO}_{2}$ and $\mathrm{CH}_{4}$ in surface waters at Mer Bleue peatland, Canada. Hydrol Proc 22:2044-2054

Billett MF, Palmer SM, Hope D, Deacon C, Storeton-West R, Hargreaves KJ, Flechard C, Fowler D (2004) Linking landatmosphere-stream carbon fluxes. Global Biogeo Cycles 18:10-24. doi:10.1029/2003gb002058

Billett MF, Deacon CM, Palmer SM, Dawson JJC, Hope D (2006) Connecting organic carbon in stream water and soils in a peatland catchment. J Geophys Res 111:1-13

Bordovskiy OK (1965) Accumulation and transformation of organic substance in marine sediments. Mar Geol 3:5-114

Butman D, Raymond PA (2011) Significant efflux of carbon dioxide from streams and rivers in the United States. Nat Geosci 4:839-842

Canton M, Anschutz P, Naudet V, Molnar N, Mouret A, Francecshi M, Naessens F, Poirier D (2010) Impact of a solid waste disposal on nutrient dynamics in a sandy catchment. J Cont Hydrol 116: $1-15$

Canton M, Anschutz P, Coynel A, Polsenaere P, Auby I, Poirier D (2012) Nutrient export to an Eastern Atlantic coastal zone: first modeling and nitrogen mass balance. Biogeochem 107:361-377

Castelle AJ, Galloway JN (1990) Carbon dioxide dynamics in acid forest soils in Shenandoah national park, Virginia. Soil Sci Soc Am J 54:252-257

Cole JJ, Caraco NF (2001) Carbon in catchments: connecting terrestrial carbon losses with aquatic metabolism. Mar Freshwat Res 52:101-110

Cole JJ, Caraco NF, Kling GW, Kratz TK (1994) Carbon dioxide supersaturation in the surface waters of lakes. Science 265 : $1568-1570$

Cole JJ, Prairie YT, Caraco NF, Mcdowell WH, Tranvik LJ, Striegl RG, Duarte CM, Kortelainen P, Downing JA, Middleburg J, Melack J (2007) Plumbing the global carbon cycle: integrating inland waters into the terrestrial carbon budget. Ecosystems 10:171-184

Dang C, Sauriau PG, Savoye N, Caill-Milly N et al (2009) Determination of diet in Manila clams by spatial analysis of stable isotopes. Mar Ecol Prog Ser 387:167-177

Dawson JJC, Billett MF, Hope D, Palmer SM, Deacon CM (2004) Sources and sinks of aquatic carbon in a peatland stream continuum. Biogeochem 70:71-92 
De Wit R, Leibreich J, Vernier F, Delmas F, Beuffe H, Maison Ph, Chossat JC, Laplace-Treyture C, Laplana R, Clavé V, Torre M, Auby I, Trut G, Maurer D, Capdeville P (2005) Relationship between land-use in the agro-forestry system of les Landes, nitrogen loading to and risk of macro-algal blooming in the bassin d'Arcachon coastal lagoon sw France. Estuar Coast Shelf Sci 62:453-465

Dubois S, Savoye N, Grémare A, Plus M, Charlier K, Beltoise A, Blanchet $H$ (2011) Origin and composition of sediment organic matter in a coastal semi-enclosed ecosystem: an elemental and isotopic study at the ecosystem space scale. J Mar Syst. doi: 10.1016/j.jmarsys.2011.10.009

Etcheber H, Taillez A, Abril G, Garnier J, Servais P, Moatar F, Commarieu MV (2007) Particulate organic carbon in the estuarine turbidity maxima of the Gironde, Loire and Seine estuaries: origin and lability. Hydrobiol 588:245-259

Finlay JC (2003) Controls of streamwater dissolved inorganic carbon dynamics in a forested watershed. Biogeochem 62:231-252

Folliot M, Pujol C, Cahuzac B, Alvinerie J (1993) Nouvelles données sur le Miocène moyen marin de Gironde-Approche des paléoenvironnements. Ciencias da Terra Lisboa 12:117-131

Frankignoulle M, Abril G, Borges AV, Bourge I, Canon C, Delille B, Libert E, Théate JM (1998) Carbon dioxide emission from European estuaries. Science 282:434-436

Frankignoulle M, Borges AV, Biondo R (2001) A new design of equilibrator to monitor carbon dioxide in highly dynamic and turbid environments. Water Res 35:344-1347

Gaillardet J, Dupré B, Louvat P, Allègre CJ (1999) Global silicate weathering and $\mathrm{CO}_{2}$ consumption rates deduced from the chemistry of large rivers. Chem Geol 159:3-30

Genereux DP, Hemond HF (1992) Determination of gas-exchange rate constants for a small stream on Walker Branch watershed, Tennessee. Water Res Res 28:2365-2374

Gillikin DP, Bouillon S (2007) Determination of $\delta^{18} \mathrm{O}$ of water and $\delta^{13} \mathrm{C}$ of dissolved inorganic carbon using a simple modification of an elemental analyzer-isotope ratio mass spectrometer EA-IRMS: an evaluation. Rapid Commun Mass Spectrom 21:1475-1478

Glé C, Amo YD, Sautour B, Laborde P, Chardy P (2008) Variability of nutrients and phytoplankton primary production in a shallow macrotidal coastal ecosystem Arcachon Bay, France. Estuar Coast Shelf Sci 76:642-656

Gran G (1952) Determination of the equivalence point in potentiometric titrations. Part II. Analyst 77:661-671

Greenwood JL, Lowe RL (2006) The effects of $\mathrm{pH}$ on a periphyton community in an acid wetland, USA. Hydrobiologia 561:71-82

Hope D, Billet MF, Cresser MS (1994) A review of the export of carbon in river water: fluxes and processes. Environ Pollut 84:301-324

Hope D, Billett MF, Cresser MC (1997) Exports of organic carbon in two river systems in NE Scotland. J Hydrol 193:61-82

Hope D, Palmer SM, Billett MF, Dawson JJC (2001) Carbon dioxide and methane evasion from a temperate peatland stream. Limnol Oceanogr 4:847-857

Hynes HBN (1983) Groundwater and stream limnology. Hydrobiol 100:93-99

Jarosz N, Brunet Y, Lamaud E, Irvine M, Bonnefond JM, Loustau D (2008) Carbon dioxide and energy flux partitioning between the understorey and the overstorey of a maritime pine forest during a year with reduced soil water availability. Agr Forest Meteorol 148:1508-1523

Johnson MS, Lehmann J, Riha SJ, Krusche AV, Richey E, Ometto JPHB, Guimarães Couto E (2008) $\mathrm{CO}_{2}$ efflux from Amazonian headwater streams represents a significant fate for deep soil respiration. Geophys Res Lett 35:L17401. doi:10.1029/2008 GL034619
Jolivet C, Augusto L, Trichet P, Arrouays D (2007) Les sols du massif forestier des Landes de Gascogne: formation, histoire, propriétés et variabilité spatiale. Revue Forestière Française 1:7-30

Jones JB, Mulholland PJ (1998) Carbon dioxide variation in a hardwood forest stream: an integrative measure of whole catchment ecosystem respiration. Ecosystems 1:183-196

Jones JB Jr, Stanley EH, Mulholland PJ (2003) Long-term decline in carbon dioxide supersaturation in rivers across contiguous United States. Geophys Res Lett 30:1495. doi:10.1029/ 2003GL017056

Kawasaki M (2002) Study on the dissolved organic carbon dynamics in the forested catchments in Japanese. MS Thesis, Kyoto University, Kyoto

Kling GW, Kipphut GW, Miller MC (1992) The flux of $\mathrm{CO}_{2}$ and $\mathrm{CH}_{4}$ from lakes and rivers in arctic. Alaska Hydrobiol 240:23-36

Legigan P (1979) L'élaboration de la formation du Sable des Landes, dépot résiduel de l'environnement sédimentaire pliocène-pléistocène centre aquitain. In. Université de Bordeaux, Bordeaux, p 429

Lundström US, Van Breemen N, Bain D (2000) The podzolization process. A review. Geoderma 94:91-107

Mantoura RFC, Woodward EMS (1983) Conservative behaviour of riverine dissolved organic carbon in the Severn Estuary: chemical and geochemical implications. Geochim Cosmochim Acta 47:1293-1309

Mehrbach C, Culberson CH, Hawley JE, Pytkowicz RN (1973) Measurement of the apparent dissociation constants of carbonic acid in seawater at atmospheric pressure. Limnol Oceanogr 18:897-907

Meybeck M (1982) River transport of organic carbon to the ocean. Am J Sci 282:401-450

Meybeck M (1987) Global chemical weathering of surficial rocks estimated from river dissolved loads. Am J Sci 287:401-428

Meybeck M (1993) Riverine transport of atmospheric carbon: sources, global typology and budget. Water Air Soil Pollut 70: 443-463

Michalzik B, Kalbitz K, Park J-H, Solinger S, Matzner E (2001) Fluxes and concentrations of dissolved organic carbon and nitrogen - a synthesis for temperate forests. Biogeochemistry 52:173-220

Miyajima T, Yamada Y, Hanba YT, Yoshii K, Koitabashi T, Wada E (1995) Determining the stable isotope ratio of total dissolved inorganic carbon in lake water by GC/C/IRMS. Limnol Oceanogr 40:994-1000

Mook WG, Tan FC (1991) Stable carbon isotopes in rivers and estuaries. In: Degens E, Kempe S, Richey J (eds) Biogeochemistry of major world rivers. Wiley, New York, pp 245-264

Mulholland PJ (2003) Large-scale patterns in dissolved organic carbon concentration, flux, and sources. In: Findlay S, Sinsabaugh RL (eds) Aquatic ecosystems-interactivity of dissolved organic matter. Academic Press, New York, pp 139-160

Neal C, Hill S (1994) Dissolved inorganic and organic carbon in moorland and forest streams: Plynlimon, mid-Wales. J Hydrol 153:231-243

Neal C, Hilton J, Wade AJ, Neal M, Wickman H (2006) Chlorophyll$a$ in the rivers of eastern England. Sci Tot Environ 365:84-104

Okazaki R (2001) Study on the export of organic carbon from a forested catchment in Japanese. MS Thesis Kyoto University Kyoto

Pace ML, Cole JJ, Carpenter SR, Kitchell JF, Hodgson JR, Van de Bogert M, Bade DL, Kritzberg ES, Bastviken D (2004) Wholelake carbon-13 additions reveal terrestrial support of aquatic food webs. Nature 427:240-243

Polsenaere P, Abril G (2012) Modelling $\mathrm{CO}_{2}$ degassing from small acidic rivers using water $p \mathrm{CO}_{2}$, DIC and $\delta^{13} \mathrm{C}$-DIC data. Geochim Cosmochim Acta 91:220-239 
Polsenaere P, Lamaud E, Lafon V, Bonnefond JM, Bretel P, Delille B, Deborde J, Loustau D, Abril G (2012) Spatial and temporal $\mathrm{CO}_{2}$ exchanges measured by Eddy Covariance over a temperate intertidal flat and their relationships to net ecosystem production. Biogeosciences 9:249-268

Probst JL (1985) Nitrogen and phosphorous exportation in the Garonne basin France. J Hydrol 76:281-305

Rantakari M, Mattsson T, Kortelainen P, Piirainen S, Finér L, Ahtianen M (2010) Organic and inorganic carbon concentrations and fluxes from managed and unmanaged boreal first-order catchments. Sci Tot Environ 408:1649-1658

Rimmelin P, Dumon JC, Maneux E, Gonçalves A (1998) Study of annual and seasonal dissolved inorganic nitrogen inputs into the Arcachon lagoon, Atlantic coast France. Estuar Co Shelf Sci 47:649-659

Savoye N, Aminot A, Tréguer P, Fontugne M, Naulet N, Kerouel R (2003) Dynamics of particulate organic matter $\delta^{15} \mathrm{~N}$ and $\delta^{13} \mathrm{C}$ during spring phytoplankton blooms in a macrotidal ecosystem Bay of Seine, France. Mar Ecol Prog Ser 255:27-41

Schindler JE, Krabbenhoft D (1998) The hyporheic zone as a source of dissolved organic carbon and carbon gases to a temperate forested stream. Biogeochemistry 43:157-174

Sharp JH (1993) The dissolved organic carbon controversy: an update. Oceanography 6:45-50

Sobek S, Tranvik LJ, Cole JJ (2005) Temperature independence of carbon dioxide supersaturation in global lakes. Glob Biogeochem Cycle 19:GB200.3. doi:10.1029/2004GB002264

Sobek S, Tranvik LJ, Prairie YT, Kortelainen P, Cole JJ (2007) Patterns and regulation of dissolved organic carbon: an analysis of 7500 widely distributed lakes. Limnol Oceanogr 52:1208-1219
Tranvik LJ, Jansson M (2002) Terrestrial export of organic carbon. Nature 415:861-862

Tranvik LJ, Downing JA, Cotner JB, Loiselle SA, Striegl RG, Ballatore TJ, Dillon P, Finlay K, Fortino K, Knoll LB, Kortelainen PL, Kutser T, Larsen S, Laurion I, Leech DM, McCallister SL, McKnight DM, Melack JM, Overholt E, Porter JA, Prairie Y, Renwick WH, Roland F, Sherman BS, Schindler DW, Sobek S, Tremblay A, Vanni MJ, Verschoor AM, von Wachenfeldt E, Weyhenmeyer GA (2009) Lakes and reservoirs as regulators of carbon cycling and climate. Limnol Oceanogr 54:2298-2314

Van Hees PAW, Jones DL, Finlay R, Godbold DL, Lundström US (2005) The carbon we do not see-the impact of low molecular weight compounds on carbon dynamics and respiration in forest soils. Soil Biol Biochem 37:1-13

Vestin JLK, Norström SH, Bylund D, Lundström US (2008) Soil solution and stream water chemistry in a forested catchment II: influence of organic matter. Geoderma 144:271-278

Vogel JC (1993) Variability of carbon isotope fractionation during photosynthesis. In: Ehleringer JR, Hall AE, Farquhar GD (eds) Stable isotopes and plant carbon-water relations. Academic Press, San Diego, pp 29-46

Worrall F, Guilbert T, Besien T (2007) The flux of carbon rivers: the case for flux from England and Wales. Biogeochemistry 86:63-75

Yang C, Telmer K, Veizer J (1996) Chemical dynamics of the 'St. Lawrance' riverine system: $\delta \mathrm{H}_{2} \mathrm{O}, \delta^{18} \mathrm{OH} 2 \mathrm{O}, \delta^{13} \mathrm{C}_{\text {DIC }}, \delta^{34} \mathrm{~S}_{\text {Sulfate }}$, and Dissolved ${ }^{87} \mathrm{Sr} /{ }^{86} \mathrm{Sr}$. Geochim Cosmochim Acta 60:851-866

Yentsch CM, Menzel DW (1963) A method for the determination of phytoplankton chlorophyll and phaeophytin by fluorescence. Deep Sea Res 10:221-231 